\title{
Autoimmunity in Wiskott-Aldrich syndrome: an unsolved enigma
}

\author{
Marco Catucci ${ }^{1}$, Maria Carmina Castiello ${ }^{1,2}$, Francesca Pala ${ }^{1}$, Marita Bosticardo ${ }^{1}$ and Anna Villa ${ }^{1,3}{ }^{*}$ \\ ${ }^{1}$ San Raffaele Telethon Institute for Gene Therapy (HSR-TIGET), Milan, Italy \\ ${ }^{2}$ Vita-Salute San Raffaele University, Milan, Italy \\ ${ }^{3}$ Milan Unit, Istituto di Ricerca Genetica e Biomedica, Consiglio Nazionale delle Ricerche, Milan, Italy
}

\section{Edited by:}

Luigi Daniele Notarangelo, Harvard

Medical School, USA

\section{Reviewed by:}

Gerben Bouma, UCL Institute of Child Health, UK

Mike Recher, University Hospital

Basel, Switzerland

Stefano Volpi, Children's Hospital

Boston, Harvard Medical School, USA

*Correspondence:

Anna Villa, San Raffaele Telethon

Institute for Gene Therapy

(HSR-TIGET), Via Olgettina 58, 20132,

Milano, Italy

e-mail:villa.anna@hsr.it
Wiskott-Aldrich Syndrome (WAS) is a severe X-linked Primary Immunodeficiency that affects 1-10 out of 1 million male individuals. WAS is caused by mutations in the WAS Protein (WASP) expressing gene that leads to the absent or reduced expression of the protein. WASP is a cytoplasmic protein that regulates the formation of actin filaments in hematopoietic cells. WASP deficiency causes many immune cell defects both in humans and in the WAS murine model, the Was $^{-1-}$ mouse. Both cellular and humoral immune defects in WAS patients contribute to the onset of severe clinical manifestations, in particular microthrombocytopenia, eczema, recurrent infections, and a high susceptibility to develop autoimmunity and malignancies. Autoimmune diseases affect from 22 to $72 \%$ of WAS patients and the most common manifestation is autoimmune hemolytic anemia, followed by vasculitis, arthritis, neutropenia, inflammatory bowel disease, and IgA nephropathy. Many groups have widely explored immune cell functionality in WAS partially explaining how cellular defects may lead to pathology. However, the mechanisms underlying the occurrence of autoimmune manifestations have not been clearly described yet. In the present review, we report the most recent progresses in the study of immune cell function in WAS that have started to unveil the mechanisms contributing to autoimmune complications in WAS patients.

Keywords: Wiskott-Aldrich syndrome, autoimmunity, primary immunodeficiency, T lymphocytes, B lymphocytes

\section{WISKOTT-ALDRICH SYNDROME: CELLULAR DEFECTS AND CLINICAL MANIFESTATIONS}

Wiskott-Aldrich Syndrome (WAS) is a rare X-linked Primary Immunodeficiency (PID) that affects $1-10$ out of a million male individuals (Ochs and Thrasher, 2006), whose life expectancy is about 15 years in severe cases (Imai et al., 2004). Affected patients demonstrate both cellular and humoral immunodeficiency, high susceptibility to infections, eczema, microthrombocytopenia, and increased risk of autoimmune disorders and lymphomas (Bosticardo et al., 2009). WAS is caused by defective expression of WAS Protein (WASP), a key regulator of cytoskeletal organization in hematopoietic cells (Figure 1). The WAS gene is located on the X chromosome and encodes a 502 amino acid protein (Derry et al., 1994), which is constitutively expressed in the cytoplasm of hematopoietic cells (Kim et al., 2000). WASP is present in an auto-inhibited conformation and its activation is mainly induced by the binding with GTPase Cell division Cycle 42 (CDC42; Abdul-Manan et al., 1999). Other factors, such as the Non-Catalytic region of tyrosine Kinase adaptor protein (NCK; Tomasevic et al., 2007), and the phosphorylation of WASP tyrosine residue 291 (Y291) can activate WASP independently of CDC42 (Cory et al., 2002; Badour et al., 2004). The binding of Phosphatidylinositol-4,5-bisphosphate $\left(\mathrm{PIP}_{2}\right)$ is also an important regulator of WASP activation by inducing a stable acting form (Imai et al., 1999). WASP, in the active form, binds the ActinRelated Protein (ARP)2/3 complex, which gives rise to nucleation of actin filaments at the side of pre-existing filaments, thus creating a branching network of actin at the plasma membrane (Symons et al., 1996; Machesky and Insall, 1998; Miki et al., 1998; Machesky and Gould, 1999; Blanchoin et al., 2000; Pantaloni et al., 2000). The activity of the ARP2/3 complex was shown to contribute to a variety of cellular functions, including change of cell shape, motility, endocytosis, and phagocytosis (Welch and Mullins, 2002).

The severity of disease, measured on the basis of the classification proposed by Zhu et al. (1997) and subsequently modified (Ochs and Thrasher, 2006; Ochs et al., 2009), is schematically reported in Table 1.

A score from one to two identifies patients affected from a milder form of the disease, named X-Linked Thrombocytopenia (XLT; Villa et al., 1995), and characterized by reduced expression of full-length mutated protein and microthrombocytopenia. Localized eczema and occasional respiratory infections, in addition to microthrombocytopenia, identify score 2 of the disease. Patients who develop microthrombocytopenia, associated with persistent but therapy-responsive eczema or infections receive a score of 3 , whereas a score of 4 is given if eczema or infections do not respond to treatments. Finally, score 5 is assigned to patients developing autoimmunity or tumors.

Wiskott-Aldrich Syndrome gene mutations are scattered throughout the entire length of the WAS gene, although some hot spots have been identified (Ochs and Thrasher, 2006). Mutations that abolish WASP expression are mainly associated with a 


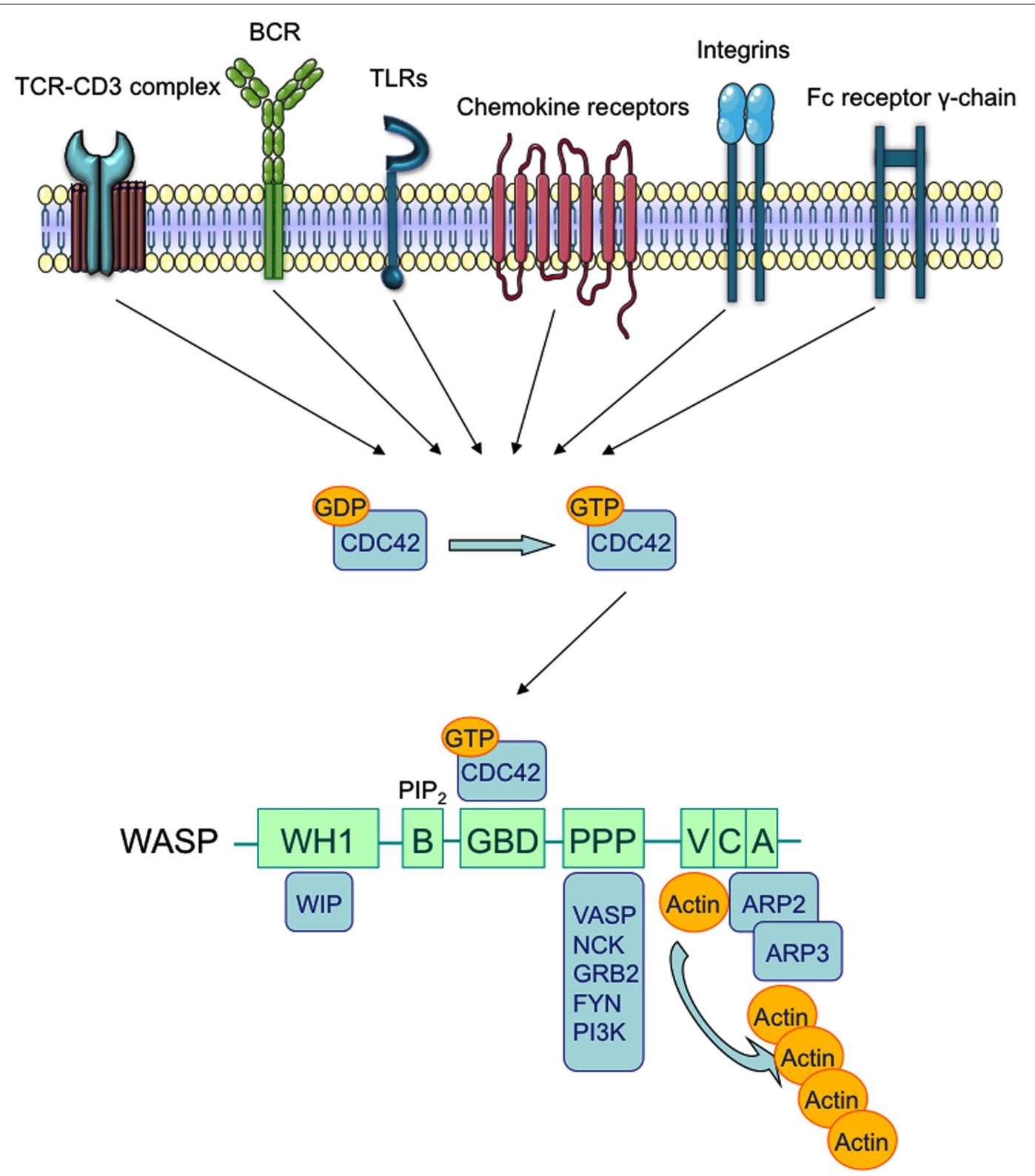

FIGURE 1 | Wiskott-Aldrich syndrome structure and interacting proteins. TCR, BCR, chemokine receptors, TLRs, integrins, and the FC receptor $\gamma$-chain can promote the release of GDP from Rho family GTPases, allowing GTP to bind. In immune cells, the major Rho GTPase is the Cell Division Cycle 42 (CDC42). The WASP-Homology 1 (WH1) domain mediates the binding to WASP-Interacting Protein (WIP; Ramesh et al., 1997). The Phosphatidylinositol-4,5-bisphosphate $\left(\mathrm{PIP}_{2}\right)$ links to the Basic (B) domain and stabilizes WASP active form. The binding of the GTPase-Binding Domain (GBD) with CDC42 induces WASP activation
(Kolluri et al., 1996; Symons et al., 1996; Miki et al., 1998). The proline-rich region (PPP) provides binding sites for the Vasodilator-Stimulated Phosphoprotein (VASP), and also for SRC family tyrosine kinases and SRC Homology $3(\mathrm{SH} 3)$ domain-containing proteins such as the adaptor proteins GRB2, FYN, PI3K, and NCK. The Verprolin-homology ( $V$ ) domain binds to actin monomers, and the Cofilin-homology (C) and Acidic (A) domains bind to the Actin-Related Protein (ARP) $2 / 3$ complex. The V/C/A region functions as the platform to initiate actin polymerization (Park et al., 2010). severe clinical phenotype (full blown WAS) and a life expectancy below 20 years of age (Jin et al., 2004). On the contrary, missense mutations, which result in residual expression of a full-length point-mutated WASP, are often associated with XLT (Villa et al., 1995; Notarangelo et al., 2002; Albert et al., 2010), corresponding to a disease score of $0.5-2$ and a longer life expectancy (Imai et al., 2004). All patients harboring mutations in the WAS gene are micro-thrombocytopenic, although intermittent X-Linked Thrombocytopenia (iXLT) is observed in some patients with substantial protein expression (Notarangelo et al., 2002). Importantly, up to $11 \%$ of patients can present somatic mosaicism due to spontaneous in vivo reversion of the original mutation or second-site compensatory mutations that restore production of the WAS gene product (Stewart et al., 2007). The revertant mutation can occur 
Table 1 |WAS scoring system according to Zhu et al. (1997), with subsequent refinements (Ochs and Thrasher, 2006; Ochs et al., 2009).

\begin{tabular}{|c|c|c|c|c|c|c|}
\hline \multirow[t]{2}{*}{ Clinical scores } & \multirow{2}{*}{$\begin{array}{l}\mathrm{iXLT} \\
<1\end{array}$} & \multicolumn{2}{|c|}{ XLT } & \multicolumn{3}{|c|}{ WAS } \\
\hline & & 1 & 2 & 3 & 4 & 5 \\
\hline Small platelets & + & + & + & + & + & + \\
\hline Eczema & - & - & $(+)$ & + & ++ & $(+) /+/++$ \\
\hline Immunodeficiency & - & $-/(+)$ & $(+)$ & + & + & $(+) /+$ \\
\hline Autoimmunity or malignancy & - & - & - & - & - & + \\
\hline
\end{tabular}

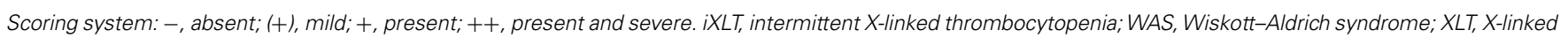
thrombocytopenia.

at various stages of hematopoietic differentiation thus conferring high selective advantage to revertant cells over mutated cell populations not expressing WASP. Although many reports describe the occurrence of this phenomenon, it is still not clear whether the presence of somatic mosaicism might correlate with a better clinical course of the disease (Davis and Candotti, 2009; Trifari et al., 2010).

Absence or residual WASP expression causes functional defects in all immune cells (Figure 2).

The formation of the Immunological Synapse (IS) in T cells and T Cell Receptor (TCR)-dependent activation (Dupre et al., 2002; Trifari et al., 2006; Nikolov et al., 2010), the cytotoxic activity of $\mathrm{CD}^{+} \mathrm{T}$ cells and Natural Killer (NK) cells (Orange et al., 2002; de Meester et al., 2010) and the suppressor activity of Naturally occurring Regulatory T (nTreg) cells (Adriani et al., 2007, 2011; Humblet-Baron et al., 2007; Maillard et al., 2007; Marangoni et al., 2007) are all impaired in WASP-deficient cells. Motility, adhesion and migration of B cells are also defective (Westerberg et al., 2005; Meyer-Bahlburg et al., 2008). Additionally, the lack of WASP affects podosome formation (Burns et al., 2001; Calle et al., 2004), motility (Binks et al., 1998; de Noronha et al., 2005) and T cell priming in Dendritic Cells (DCs; Pulecio et al., 2008; Bouma et al., 2011), as well as podosome and phagocytic cup formation in macrophages (Linder et al., 1999; Tsuboi and Meerloo, 2007). Invariant Natural Killer T (iNKT) cell functionality (Astrakhan et al., 2009; Locci et al., 2009), adhesion, and migration of neutrophils (Zhang et al., 2006) are also altered in the absence of WASP. Moreover, WASP is also involved in signal transduction (Figure 3). In particular, TCRdependent nuclear recruitment of Nuclear Factor of Activated T cells (NFAT) -1 in CD4 ${ }^{+} \mathrm{T}$ cells and both NFAT- 1 and NFAT-2 in $\mathrm{CD}^{+} \mathrm{T}$ cells are reduced in WAS patients and correlate with defective Th1 cytokine production (Cianferoni et al., 2005; Trifari et al., 2006). Additionally, WASP is involved in B Cell Receptor (BCR) signaling by binding to the Src homology three domains of several tyrosine kinases, such as the Bruton's Tyrosine Kinase (BTK; Cory et al., 1996; Sharma et al., 2009).

The most common finding in WAS patients is microthrombocytopenia which causes frequent hemorrhages in more than $80 \%$ of patients (Ochs, 2002; Imai et al., 2004) and severe bleeding episodes that lead to death in $4-10 \%$ of patients (Sullivan et al., 1994; Imai et al., 2004). The mechanism underlying thrombocytopenia is not completely understood. One possible explanation could be an abnormal platelet clearance induced by an increased exposure of phosphatidylserine on the outer plasma membrane of WASP-deficient platelets (Shcherbina et al., 2009). Another mechanism of platelet reduction that needs to be investigated more in detail, is the elimination mediated by autoimmune reaction. In fact, the presence of platelet-associated antibodies in $\mathrm{Was}^{-1-}$ mice (Marathe et al., 2009) and in some patients has been reported (Corash et al., 1985; Semple et al., 1997). The second most common manifestation in WAS patients is the eczema. It is observed in $80 \%$ of patients and its severity inversely correlates with the expression of WASP. Indeed, it has been shown that WAS patients with residual WASP expression develop moderate or transient form of the disease, whereas most of WASP-negative patients develop severe, treatment-resistant eczema (Imai et al., 2004). High IgE levels (more than $1000 \mathrm{IU} / \mathrm{mL}$ ) were observed in $62 \%$ of WASPnegative patients and in 25\% of WASP-positive. Although higher IgE levels may represent a possible cause of eczema, the correlation between increased IgE levels and eczema has not yet been demonstrated. WAS patients are highly susceptible to infections by bacteria, viruses, and fungi (Imai et al., 2004). Of note, WASP-negative patients are more frequently affected by bacterial infections (otitis media, skin abscess, pneumonia, enterocolitis, meningitis, sepsis, urinary tract infection, and others), viral infections (Herpes simplex and Cytomegalovirus) and fungal infections (Candida spp., Aspergillus spp., and Pneumocystis carinii) as compared to WASPpositive patients (Imai et al., 2004). Patients with clinically most severe WAS develop malignancies and/or autoimmune manifestations. Malignancies can affect adolescent and young adult WAS patients more than infants (Sullivan et al., 1994; Imai et al., 2004). Epstein-Barr virus (EBV)-positive B cell lymphoma is most frequently reported, but also myelodysplasia can be observed in some patients (Imai et al., 2004). Autoimmune complications are frequently observed in WAS, affecting $22-72 \%$ of patients (Dupuis-Girod et al., 2003; Imai et al., 2004). WAS patients with autoimmune diseases constitute a high-risk group with poor prognosis. Moreover, autoimmunity is associated with a higher risk of a later development of tumors and an increased risk of mortality (Sullivan et al., 1994). A better understanding of the mechanisms underlying autoimmunity in WAS would be crucial for the development of more effective therapies for the management of these manifestations in WAS and could also provide new insights in the pathogenesis of autoimmunity in PIDs. 

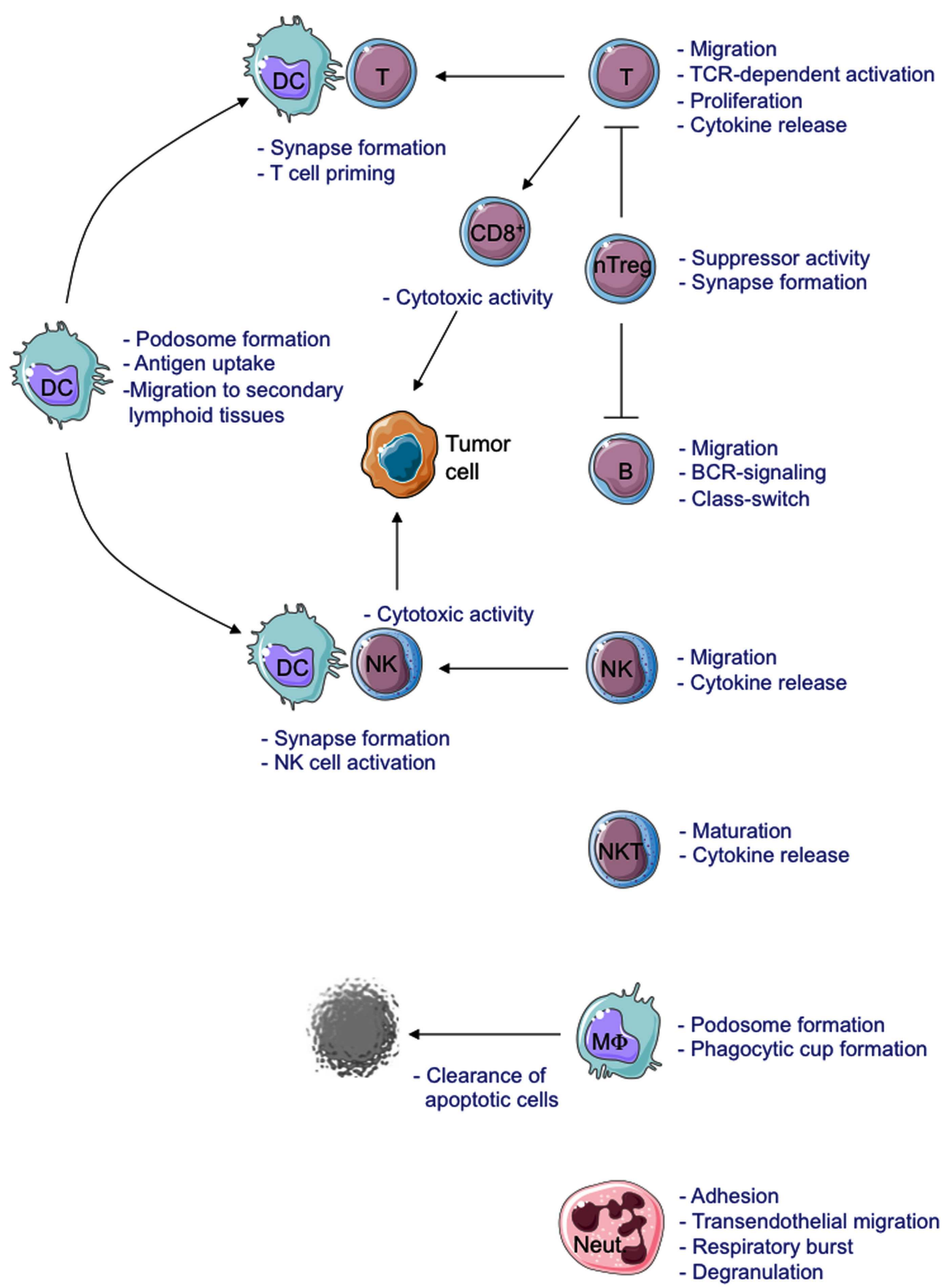

FIGURE 2 | Schematic view of cellular defects described in WASP-deficient cells. MФ, Macrophage; Neut., Neutrophil.

\section{AUTOIMMUNE MANIFESTATIONS IN WAS PATIENTS AND} CURRENT TREATMENTS

The most common autoimmune manifestation in WAS is hemolytic anemia (36\%), followed by vasculitis (including cerebral vasculitis; 29\%), arthritis (29\%), neutropenia (25\%), inflammatory bowel disease (9\%), and $\operatorname{IgA}$ nephropathy (3\%). Henoch-Schönlein-like purpura, dermatomyositis, recurrent angioedema, and uveitis have also been reported in some patients (Dupuis-Girod et al., 2003; Imai et al., 2004). Moreover, multiple autoimmune manifestations can be observed. In most cases, and 


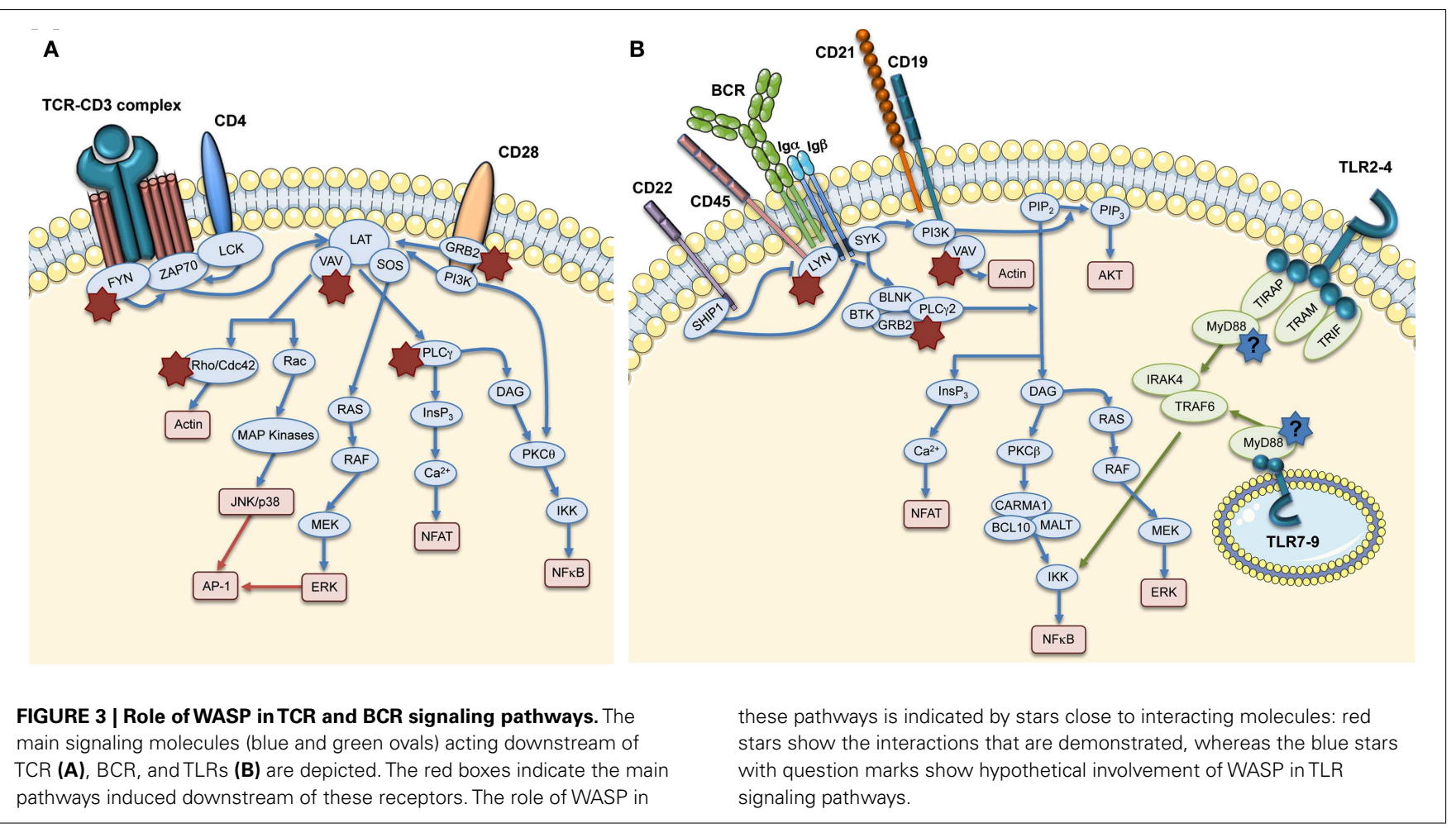

in all cases of hemolytic anemia, the onset of autoimmune complications occurs early in life ( $0-5$ years; Dupuis-Girod et al., 2003). Interestingly, it has been recently found that $\mathrm{Was}^{-1-}$ mice develop proliferative glomerulonephritis with increased IgA in the serum and IgA production by splenic B cells (Nikolov et al., 2010; Shimizu et al., 2012). Moreover old $\mathrm{Was}^{-1-}$ mice showed aberrant glycosylation of IgA (Shimizu et al., 2012), feature that has been associated to the development of nephropathy-like glomerular lesions with IgA deposition (Nishie et al., 2007). Although these studies have been performed on WAS mouse model, they clearly suggest a possible mechanism for the pathogenesis of glomerulonephritis in WAS patients.

Clinical management of WAS patients is a significant challenge since, with the exception of Bone Marrow Transplantation (BMT), most available therapies are not curative. Intravenous immunoglobulins (IVIG) and antibiotic prophylaxis are often used to reduce the risk of infections in WAS patients, but it is not clear whether these treatments effectively reduce the incidence of life-threatening infections (Conley et al., 2003). Splenectomy significantly increases and often normalizes the platelet counts (Corash et al., 1985; Mullen et al., 1993). However, it does not fully overcome the risk of bleeding and further predisposes to sepsis, obliging the patients to life-long antibiotic prophylaxis (Mullen et al., 1993). Relapse of thrombocytopenia has been described in a fraction of splenectomized WAS patients (Corash et al., 1985; Dupuis-Girod et al., 2003). Of note, in some cases, thrombocytopenia was found to be autoantibody-mediated and also associated with hemolytic anemia or cerebral vasculitis (DupuisGirod et al., 2003). Therefore, splenectomy is indicated only in severe cases, for which there is no prospect for other curative interventions. Treatment with human recombinant Interleukin
2 (hrIL-2) appeared to be effective in reducing herpes virus infections and improving dermatitis in a WAS patient (Azuma et al., 1993). Administration of hrIL-2 ameliorated proliferation of cultured $\mathrm{T}$ cells from one patient (Azuma et al., 2000) and restored cytotoxicity and actin accumulation at the IS in NK cells from another treated patient (Orange et al., 2011). Since WAS T cells are less efficient in producing IL-2, NK cells do not receive sufficient IL-2, thus resulting in reduced NK activation and failure to respond effectively to infections. A clinical trial with hrIL-2 is currently ongoing in WAS (ClinicalTrials.gov identifier NCT00774358). The treatment of choice for autoimmune manifestations in WAS patients consists of steroids, alone, or in association with cyclosporine (Dupuis-Girod et al., 2003). Steroids are the first-line treatment for all patients with hemolytic anemia and efficiently induce remission in $10 \%$ of cases, are partially effective in $60 \%$ of cases, while are ineffective in $30 \%$ of cases. Cyclophosphamide and azathioprine are also used in some cases and are effective in a small percentage of cases. Patients with severe autoimmune thrombocytopenia after splenectomy are usually treated with IVIG, high-dose steroids, azathioprine, and cyclophosphamide. Other autoimmune or inflammatory complications are generally treated with steroids, in association with cyclosporine, and are effective in the majority of skin vasculitis, arthritis, bowel inflammatory disease and renal disease cases (Dupuis-Girod et al., 2003). Anti-CD20 monoclonal antibody therapy has been also performed for the treatment of autoimmune hemolytic anemia in some patients. This treatment results effective in correcting the anemia, but it may need repeated courses due to relapse of the disease (Ship et al., 2002; Kim et al., 2007).

Currently, the only resolutive therapeutic option for WAS patients is BMT. When a Related HLA-Identical Donor (RID) is 
available, BMT leads to 73-100\% survival (Mullen et al., 1993; Ozsahin et al., 1996, 2008; Filipovich et al., 2001; Antoine et al., 2003; Kobayashi et al., 2006; Pai et al., 2006; Moratto et al., 2011). On the other hand, transplantation using the bone marrow of a Mismatched Related Donor (MMRD) results in a poor survival ranging from 29 to $52 \%$ (Mullen et al., 1993; Filipovich et al., 2001; Kobayashi et al., 2006; Ozsahin et al., 2008). In addition, this type of transplant is associated with an elevated risk of developing life-threatening $\mathrm{EBV}^{+}$lymphoproliferative syndrome, infections, autoimmunity, and graft-versus-host disease (GVHD; Filipovich et al., 2001), therefore it is not recommended except in case of emergency. When a suitable related donor is missing, transplantation using the bone marrow or cord blood from a Matched Unrelated Donor (MUD) is a valid therapeutic option, leading to 71-81\% survival (Filipovich et al., 2001; Kobayashi et al., 2006; Pai et al., 2006). Two recent retrospective studies have analyzed longterm outcome and donor cell engraftment in WAS patients who have been treated by Hematopoietic Stem Cell Transplantation (HSCT; Ozsahin et al., 2008; Moratto et al., 2011). They observed that $20 \%$ of patients developed autoimmune manifestations after HSCT independently of chronic GVHD (Ozsahin et al., 2008) and some patients had more than one manifestation. Autoimmune manifestations appeared at a median of 1.5 years after HSCT (range: 4 months to 10 years). The median duration of autoimmunity was 4 years (range: $1-20$ years). Autoimmune manifestations were more frequent in recipients of MUD (28\%) and MMRD (26\%) than RID HSCT (11\%). Ozsahin and colleagues investigated whether patients developing autoimmunity after HSCT had autoimmune manifestations also before treatment. Overall, 17 patients had autoimmune manifestations before transplantation that persisted thereafter in seven of them. Conversely, autoimmunity occurred de novo in $11-23 \%$ of transplanted patients. A very interesting observation in both retrospective studies was the strong correlation between autoimmunity occurrence and the chimerism pattern. Overall, incomplete reconstitution of lymphocyte counts and incidence of autoimmunity were higher in patients with a lower degree of chimerism in both lymphoid and myeloid compartments as compared to patients with full chimerism (Ozsahin et al., 2008; Moratto et al., 2011).

A very promising alternative to HSCT, when a matched donor is missing, is the infusion of gene corrected autologous Hematopoietic Stem Cells (HSCs). Two different Gene Therapy (GT) clinical trials have been approved: a Retroviral Vector (RV)-mediated gene transfer (Boztug et al., 2010) and a Lentiviral Vector (LV)-mediated GT approach, developed by our and other groups (Dupre et al., 2006; Galy et al., 2008). In the RV-mediated clinical trial, sustained expression of WASP in HSCs, lymphoid and myeloid cells, and platelets was shown in two treated patients 3 years after GT (Boztug et al., 2010). T and B cells, NK cells, and monocytes were also functionally corrected resulting in improved clinical conditions. Signs and symptoms of autoimmunity disappeared in both patients within the first year after GT. In one of the two reported patients, severe autoimmune hemolytic anemia, autoimmune thrombocytopenia, and autoimmune neutropenia disappeared; whereas severe eczema resolved in the second patient. However, in this trial, leukemia occurred in one out of ten GT patients, probably due to insertional mutagenesis caused by RV integration
(Press Release, Hannover Medical School, http://www.asgct.org/ UserFiles/file/Genetherapy_WAS_final_english.pdf). This adverse event gives rise to some concerns on the safety of RV-mediated GT for WAS. A multicenter clinical trial using a third generation LV carrying WAS gene driven by the endogenous promoter is on going in Milan, Paris, and London. Preclinical data in the murine model indicate that the LV-mediated GT approach is effective in restoring immune cell functionality (Blundell et al., 2008; Marangoni et al., 2009; Bosticardo et al., 2011; Catucci et al., 2011). GT treated $\mathrm{Was}^{-1-}$ mice did not show any adverse events or tumors even in long-term follow up studies (Marangoni et al., 2009). Finally, we and others demonstrated the efficacy of LV-mediated GT in CD34 ${ }^{+}$cells obtained from WAS patients (Charrier et al., 2007; Scaramuzza et al., 2012). Nevertheless, data from the clinical study are needed to provide definitive evidence of the efficacy and safety of this novel therapeutic approach.

\section{REGULATION OF T CELL TOLERANCE IN WAS}

$\mathrm{T}$ cells are significantly reduced in peripheral blood of WAS patients and show a defective proliferation in response to TCR stimulation by $\mathrm{CD} 3$-specific antibody, although this defect is present only at low doses of agonistic antibody (Molina et al., 1992, 1993). TCR-dependent activation in WASP-deficient T cells results in a reduced IL-2 production (Molina et al., 1993), that is associated with delayed NFAT-1 nuclear translocation and defective T-bet induction (Cianferoni et al., 2005; Trifari et al., 2006; Taylor et al., 2010). T cell activation is regulated by the formation of the IS, a polarized cluster of TCR, costimulatory molecules, signaling molecules, and integrins at the $\mathrm{T}$ cell:antigen presenting cell (APC) interface. To promote their lateral movement on the plasma membrane, the molecules being recruited to the IS are associated with specific cholesterol-enriched membrane microdomains, called lipid rafts. In the absence of WASP, IS can be formed only after strong TCR stimulation (Cannon and Burkhardt, 2004). In particular, WASP-deficient T cells fail to upregulate GM1 on the cell surface, cluster GM1 in the lipid rafts during IS formation (Dupre et al., 2002) and maintain IS stability after migration (Sims et al., 2007).

It is commonly assumed that autoimmunity is a consequence of the breakdown of central or peripheral tolerance to self-antigens. $\mathrm{nTreg}$ cells are fundamental to maintain tolerance to self-antigens and suppress excessive immune responses. nTreg cell development and function depend on TCR signaling, together with CD28 recruitment, FOXP3 expression, and presence of IL-2 (Sakaguchi et al., 2008). Several groups, including ours, have described the defects of nTreg cells in WAS patients and $\mathrm{Was}^{-1-}$ mice in localizing and suppressing $\mathrm{T}$ effector cell response (Adriani et al., 2007; Maillard et al., 2007; Marangoni et al., 2007), although their number in blood of WAS patients is comparable with healthy donors (Marangoni et al., 2007). It is not clear whether a defective thymic development of $\mathrm{Was}^{-1-}$ nTreg cells could account for their impaired in vivo suppressive function, since one group has shown reduced nTreg cell percentage in the thymus (Maillard et al., 2007), while three other groups observed normal frequency while showed a reduced function in vivo (Adriani et al., 2007; Humblet-Baron et al., 2007; Marangoni et al., 2007), but all showed a reduced in vivo suppression. $\mathrm{Was}^{-/-}$nTreg cell failure to control 
aberrant $\mathrm{T}$ cell activation has been also demonstrated in vivo in a mouse model of autoimmunity (Humblet-Baron et al., 2007). Moreover, selective advantage of WASP-expressing nTreg cells was shown in a WAS patient with revertant mutation, demonstrating that WASP has a role in nTreg cell fitness (Humblet-Baron et al., 2007). Although the requirement of WASP for nTreg cell functionality has been demonstrated, the role of WASP in these cells is still unclear. Indeed, differently from effector T cells, WASP is not recruited to the IS (Marangoni et al., 2007), thus suggesting a possible role of WASP in TCR signaling of nTreg cells. Moreover, WASP-deficient nTreg cells are also defective in suppressing $\mathrm{B}$ cell activation. In fact, it has been shown in in vitro studies that nTreg cells from $\mathrm{Was}^{-1-}$ mice are less efficient in turning off B cell proliferation and this defect is associated with a reduced killing of B cells and significantly decreased secretion of granzyme B by nTreg cells (Adriani et al., 2011). Susceptibility of WAS patients to develop autoimmune diseases can be at least in part explained by nTreg cell dysfunction.

Recent findings have demonstrated that also $\mathrm{T}$ effector cells are implicated in tolerance breakdown in WAS. Indeed, in response to restimulation through the TCR, activated T cells can undergo apoptosis, and this event is called restimulation-induced cell death (RICD; Lenardo, 1991; Siegel et al., 2000). RICD process contributes to the maintenance of peripheral immune tolerance by eliminating $\mathrm{T}$ cells responding to prolonged presence of antigens, such as self-antigens and persistent pathogen antigens (Critchfield et al., 1994; Ettinger et al., 1995; Weant et al., 2008). In CD4 ${ }^{+} \mathrm{T}$ cells, RICD is induced by the Tumor Necrosis Factor (TNF) family member Fas ligand (FasL) that is released and binds its receptor Fas in an autocrine fashion (Critchfield et al., 1994; Ettinger et al., 1995; Siegel et al., 2000; Green et al., 2003; Weant et al., 2008). Nikolov and colleagues have shown that WASP is required for T cell apoptosis by RICD. In the absence of WASP, the release of FasL by $\mathrm{CD}^{+} \mathrm{T}$ cells is reduced and this is associated to a decreased TCRmediated apoptosis (Nikolov et al., 2010). Together with nTreg cell defects, these recent findings highlight the role played by effector $\mathrm{T}$ cells in the maintenance of $\mathrm{T}$ cell tolerance in WAS.

\section{REGULATION OF B CELL TOLERANCE IN WAS}

In the last years, many studies have assessed the role of B cells in driving autoimmune diseases such as Rheumatoid Arthritis (RA), Multiple Sclerosis (MS), and Systemic Lupus Erythematosus (SLE; Townsend et al., 2010). These data revealed the complex role of B cells that work independently or synergistically with other components of the innate and adaptive immune system to drive autoimmune pathogenesis.

For many years, the functionality of B cells in WAS patients was poorly investigated. The presence of a skewed distribution of serum Ig isotypes (reduced IgM, normal IgG, and elevated IgE and IgA levels) and a reduced or absent antibody production to polysaccharides and other $\mathrm{T}$ cell-independent antigens (Golding et al., 1984; Ochs and Thrasher, 2006) represent the first evidences of a defective B cell effector function in WAS patients. This prompted many researchers to investigate more in detail the $\mathrm{B}$ cell compartment in WAS, mainly taking advantage of the murine model of the disease (Was ${ }^{-1-}$ mice). In the last decade, it has been clearly defined that the lack of WASP causes defects in the cytoskeletal functions of B cells, including adhesion, migration, and homing (Westerberg et al., 2005, 2008; Meyer-Bahlburg et al., 2008). These defects may compromise the capacity of B cells to be properly activated and reach the site of infection contributing to the inability of the immunodeficient host to completely eradicate infectious agents. In this respect, it has been accepted, in particular for PIDs, that chronic immune response due to an incomplete pathogen clearance may favor breakdown of peripheral tolerance. Of note, the complement receptors CD21 (CR2) and CD35 (CR1) are expressed at lower levels on B cells of patients with WAS (Park et al., 2005) contributing to a suboptimal B cell capacity to capture and present opsonized antigens. Additionally, given the critical role of CD21 and CD35 in the negative selection of self-reactive B cells (Prodeus et al., 1998), the altered expression or function of these receptors may affect the maintenance of $\mathrm{B}$ cell tolerance in Immune Complex (IC)-mediated autoimmune diseases such as SLE and RA (Erdei et al., 2009).

The fate of self-reactive B cells within the bone marrow and peripheral lymphoid compartment is largely determined by the strength of signal mediated by BCR in response to antigen crosslinking (Nemazee and Burki, 1989; Erikson et al., 1991; Goodnow, 1996). To this regard, reports of a defective BCR activation are controversial. Activation of WASP-deficient B cells was found to be defective after BCR engagement in terms of calcium mobilization in primary B cells isolated from WAS patients and also in WASP-deficient EBV-transformed B cell lines (Simon et al., 1992). However, this defect was not confirmed by Henriquez et al. (1994). More recently, studies performed on $\mathrm{Was}^{-/-}$mice showed a normal proliferative response of B cells after stimulation with anti-IgM, LPS, or anti-CD40 (Snapper et al., 1998; Zhang et al., 1999) and a normal or increased class switch (Westerberg et al., 2005). However, the presence of circulating autoantibodies in WAS patients (Dupuis-Girod et al., 2003; Schurman and Candotti, 2003) and in $\mathrm{Was}^{-1-}$ mice (Humblet-Baron et al., 2007; Nikolov et al., 2010; Becker-Herman et al., 2011; Bosticardo et al., 2011) represents the first evidence of a perturbed B cell tolerance. Very recently, two studies have shown the contribution of B cell intrinsic defects to the pathogenesis of autoimmunity in two different murine models. Indeed, Becker-Herman et al. (2011) observed that female $\mathrm{Was}^{+/-}$mice generate anti-nuclear antibodies at rates and titers equivalent to $\mathrm{Was}^{-1-}$ mice even though heterozygous animals have a normal nTreg cell compartment. Based on this evidence, they demonstrated in mixed BM chimeras, in which only B cells lacked WASP expression, that the selective defect in B cells is sufficient for the generation of autoantibodies. Additionally, they suggested that BCR/Toll-Like Receptor (TLR) co-engagement in Was $^{-1-}$ B cells from chimeras could mediate tolerance breakdown, since the loss of Myeloid Differentiation primary response gene 88 (MyD88) signaling abolished the production of anti-dsDNA antibodies, germinal center formation, and development of systemic autoimmune disease (Becker-Herman et al., 2011). More recently, by conditional WAS gene deletion in $\mathrm{B}$ cells $(\mathrm{B} / \mathrm{WcKO}$ mice), Recher et al. (2012) observed that WASP deficiency limited to $\mathrm{B}$ cells is sufficient to promote autoantibody production and kidney tissue damage in $\mathrm{B} / \mathrm{WcKO}$ mice.

Overall, these findings highlight the contribution of $\mathrm{B}$ cells to the pathogenesis of autoimmunity in WAS and suggest that the B 
cell autonomous defect could represent a sufficient factor to break tolerance in WAS. However, in addition to the supposed role for TLR signaling in the autoreactivity of $\mathrm{Was}^{-1-} \mathrm{B}$ cells, other mechanisms are potentially involved and need to be further investigated both in mice and humans.

\section{FUTURE DIRECTIONS}

WAS is characterized by a very complex spectrum of cellular defects, many of which can predispose patients to the development of autoimmunity (Figure 4).

As described above, defective control of the strength of immune response by nTreg cells, the presence of autoantibodies and potentially autoreactive B cells have been demonstrated in WAS (Bosticardo et al., 2009). However several mechanisms shown to be involved in the pathogenesis of autoimmune diseases still need to be investigated in WAS. iNKT cells have been shown to prevent autoimmune disease in a mouse model of experimental Autoimmune Encephalomyelitis (EAE; Miyamoto et al., 2001; Singh et al.,
2001) and uveitis (Oh et al., 2011). Although the mechanisms have not been fully understood, it has been shown that iNKT activation reduces autoimmune symptoms by limiting the development of Th17 cells in a cell contact- and cytokine-dependent manner (Mars et al., 2009). Moreover, in mice, iNKT cells suppress anti-DNA antibody production and reduce autoreactive $\mathrm{B}$ cells (Yang et al., 2011), whereas iNKT reduction leads to increased autoreactive B cell activation (Wermeling et al., 2010). Since iNKT cells are reduced in WAS patients and functionally defective in $\mathrm{Was}^{-1-}$ mice (Astrakhan et al., 2009; Locci et al., 2009) it can be hypothesized that such impairment may also contribute to autoimmunity.

A mechanism contributing to the tolerance breakdown in PIDs is related to the inability of innate immune cells, in particular DCs, to properly activate adaptive immune response (Arkwright et al., 2002). Since DCs have a role in the induction of nTreg cells (Manicassamy and Pulendran, 2011) and DCs lacking WASP are defective in T cell priming (Bouma et al., 2007; Pulecio et al., 2008), it is

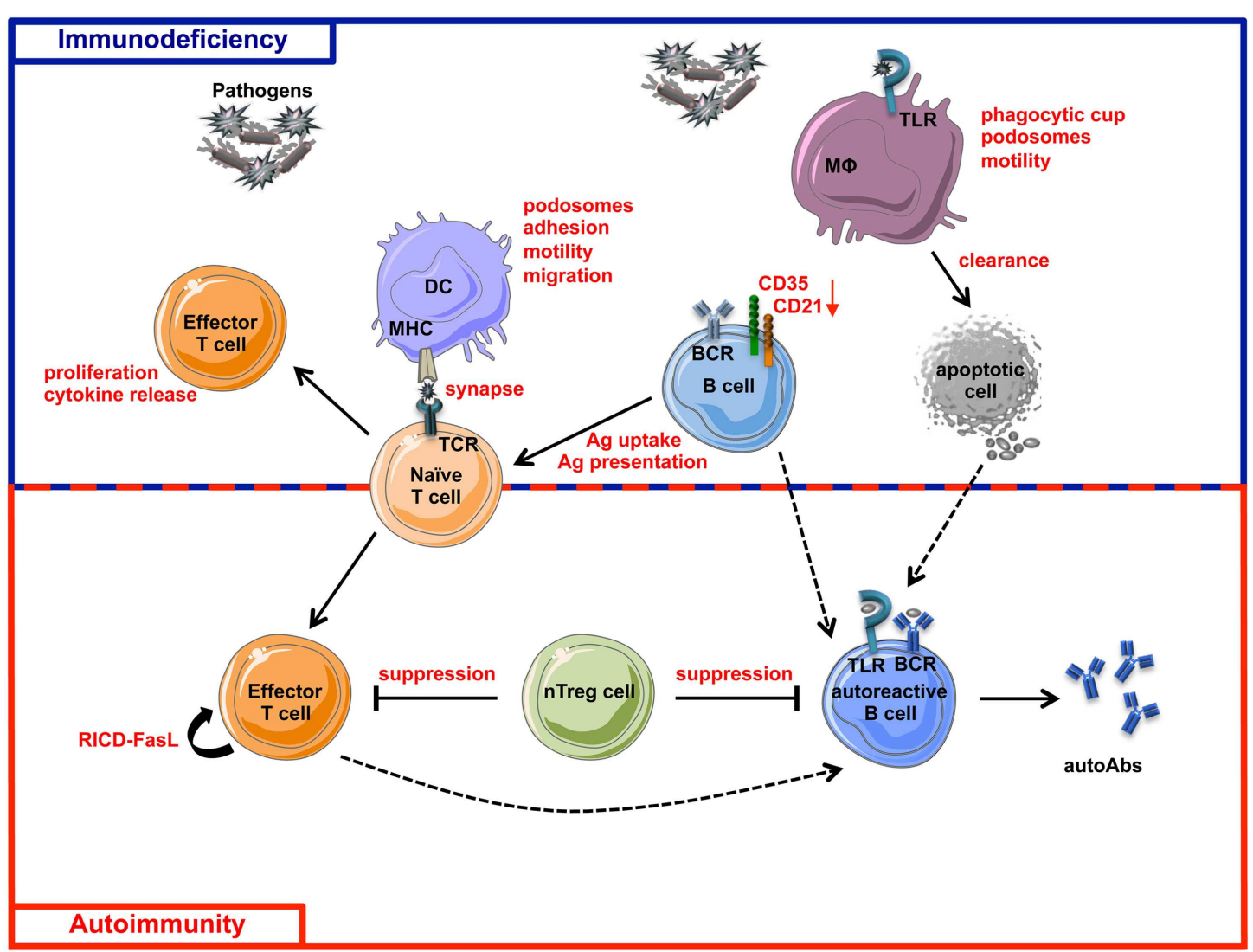

FIGURE 4 | Schematic view of immunodeficiency and autoimmunity in WAS. The impairment of both innate and adaptive immune systems is responsible of immunodeficiency (blue box) and autoimmunity (red box) in WAS. Immune cell defects described in WASP-deficient cells are shown in red. The incomplete pathogen clearance is sustained by cytoskeleton and functional defects of macrophages, DCs, T cells, B cells, and their defective interactions. The reduced expression of $\mathrm{CD} 21$ and $\mathrm{CD} 35$, two complement receptors involved in antigen uptake and presentation and also in negative selection of self-reactive $B$ cells, places $B$ cells at the interface between immunodeficiency and autoimmunity. Defective suppression of WASP-deficient $n$ Treg cells toward both $T$ and B cells contributes to the tolerance breakdown in WAS. Defect in RICD process, resulting in defective effector $T$ cell apoptotic death after TCR restimulation, concurs in the persistence of $\mathrm{T}$ cell response to pathogens or self-antigens. Additionally, intrinsic B cell defects contribute to autoimmunity in WAS, probably via a TLR-mediated mechanism. Dashed lines represent hypothetical mechanisms involved in WAS-related autoimmunity. MHC, Major Histocompatibility Complex; RICD, Restimulation-Induced Cell Death; autoAbs, autoantibodies; Ag, Antigen. 
possible to hypothesize that a defect in nTreg cell induction by DCs might occur in the absence of WASP. Immunodysregulation can be also sustained by overload of pathogen antigens or apoptotic material due to defective clearance by innate immune cells. Antigen overload in fact results in a prolonged immune response, which promotes expansion of Th17 cell subset, playing a central role in many autoimmune diseases, such as MS, RA, and Crohn's disease (Langrish et al., 2005; Fouser et al., 2008; Isaksson et al., 2009; Sharma et al., 2009). Furthermore, reduced clearance of apoptotic material has been associated to the accumulation of autoantibodies in SLE (Gaipl et al., 2005; Fransen et al., 2012). WASP-deficient DCs are impaired in antigen uptake and migration to secondary lymphoid tissues (Westerberg et al., 2003; de Noronha et al., 2005) suggesting an inefficient pathogen clearance, process that needs to be investigated in in vivo models of infection. Moreover, WASPdeficient macrophages are less efficient in uptaking apoptotic cells both in vitro and in vivo (Leverrier et al., 2001). All together, these findings suggest that dysregulation of Th17 cell activation might contribute to autoimmunity induction in WAS patients, although no evidence has been provided so far to sustain such hypothesis.

Recent studies have demonstrated the key role played by a specific subset of DCs, namely plasmacytoid DCs (pDCs), in the pathogenesis of systemic autoimmune diseases. In particular, IFN$\alpha$ produced by $\mathrm{pDC}$ upon recognition of foreign nucleic acids via TLR7 and TLR9 contributes to tolerance breakdown in several autoimmune diseases, such as SLE, SS, and psoriasis (Ronnblom, 2011). In these clinical settings, self-nucleic acid-containing ICs trigger TLR7 or TLR9 leading to an uncontrolled pDCs activation. In PIDs, an increased susceptibility to viral infection, in combination with a defective clearance of pathogens, could be the triggering factor of the over-activation of type I IFN pathway. Moreover, cell death induced by viral infection leads to the release and accumulation of self-antigens in the extracellular matrix. Since PID patients, including WAS patients, are highly susceptible to infections and fail to completely eradicate the pathogens, high levels of ICs and activation of the type I IFN system can be expected. Furthermore, increasing evidences highlight the role played by neutrophils in SLE in the induction of type I IFN production. Mature neutrophils are primed in vivo by type I IFN and die upon exposure to antiribonucleoprotein antibodies, releasing neutrophil extracellular traps (NETs) which in turn activate pDCs to produce high levels of type I IFN (Garcia-Romo et al., 2011). Overall, these studies have demonstrated an important role of neutrophils and pDCs in promoting autoimmune diseases and it can be envisaged that these mechanisms may act in the complexity of WAS autoimmunity.

Triggering of autoreactive B cells by self-nucleic acidcontaining ICs can be another possible mechanism underlying the production of autoantibodies in WAS. In fact, it is known that self-nucleic acid-containing ICs can activate B cells through synergistic engagement of BCR and TLR7 or TLR9 (Leadbetter et al., 2002; Lau et al., 2005; Chaturvedi et al., 2008), and the loss of MyD88 signaling in Was $^{-/-}$mice abolish the production of anti-dsDNA antibodies (Becker-Herman et al., 2011). The recent findings of B cell intrinsic defect (Becker-Herman et al., 2011; Recher et al., 2012) open a new scenario in tolerance breakdown in WAS although the underlying mechanisms are still unclear. It is known that B cell tolerance is established through central and peripheral checkpoints during B cell maturation which require proper BCR and TLR signaling together with extrinsic factors (Meffre, 2011). The cytoskeleton controls the distribution of the BCR and shapes its signaling (Batista et al., 2010). In particular, the density of actin network inversely correlates with the rate of BCR diffusion and the restriction of BCR diffusion limits signaling. Since WASP is required for actin polymerization and cytoskeletal organization in B cells (Facchetti et al., 1998; Westerberg et al., 2005), it is reasonable to speculate that the threshold of activation might be altered in WASP-deficient B cells. In the bone marrow, receptor editing is the major mechanism aimed at eliminating selfreactive $\mathrm{B}$ cells during differentiation (Monroe and Dorshkind, 2007; von Boehmer and Melchers, 2010) by editing autoreactive receptors through secondary rearrangements in light chain loci (Halverson et al., 2004). Abnormal receptor editing is involved in the loss of central B cell tolerance (Ng et al., 2004). Interestingly, alterations in the regulation of secondary recombination events have been reported in BTK-, Interleukin-1 Receptor-associated Kinase 4 (IRAK4)-, and MyD88-deficient patients and in a group of Common Variable Immunodeficiency (CVID) patients with expanded autoreactive CD21-/low B cells ( $\mathrm{Ng}$ et al., 2004; Isnardi et al., 2008; Meffre, 2011). Given the interaction of WASP with BTK (Cory et al., 1996; Sharma et al., 2009), the involvement of MyD88 signaling in B cell tolerance (Becker-Herman et al., 2011) and the increased frequency of CD21- B cells in WAS patients (Park et al., 2005), it would be worth to investigate whether receptor editing is defective also in the absence of WASP. Furthermore, in the periphery, survival of autoreactive B cells is supported by high levels of BAFF and APRIL, members of the TNF superfamily, found to be increased in several autoimmune diseases (Townsend et al., 2010) and lymphopenic conditions (Cassani et al., 2010). This represents an important mechanism involved in the regulation of peripheral human B cell tolerance that would be interesting to investigate in WAS. Finally, a new function as regulator of immune response has been described for B cells and is mainly mediated by the secretion of IL-10 (Matsushita et al., 2008; Yanaba et al., 2009; Watanabe et al., 2010). Although the origin of regulatory B cells is unclear, MZ B cells (Lenert et al., 2005; Evans et al., 2007) seem to have regulatory functions. Thus, considering the reduction of MZ B cells in Was $^{-1-}$ mice (Westerberg et al., 2008; Bosticardo et al., 2011), it would be interesting to investigate whether a defect in regulatory $\mathrm{B}$ cell function is a factor contributing to autoimmunity.

In conclusion, together with the defects already described in the literature, these future lines of enquiry underline the greater than expected extent to which the WASP deficiency affects the immune system. Further research is necessary to define the underlying molecular and cellular mechanisms leading to autoimmunity, which represents the main collateral damage caused by WASP deficiency.

\section{ACKNOWLEDGMENTS}

This work was supported by grants from Italian Telethon Foundation (to Anna Villa), and Ministero della Salute RF 2007-2008-2009 Giovani Ricercatori Grant (to Marita Bosticardo). Maria Carmina Castiello conducted this study as partial fulfillment of her $\mathrm{PhD}$. in Molecular Medicine, Program in Basic and Applied Immunology, San Raffaele University, Milan, Italy. Figures were produced using Servier Medical Art (www.servier.com). 


\section{REFERENCES}

Abdul-Manan, N., Aghazadeh, B., Liu, G. A., Majumdar, A., Ouerfelli, O., Siminovitch, K. A., and Rosen, M. K. (1999). Structure of Cdc42 in complex with the GTPase-binding domain of the 'Wiskott-Aldrich syndrome' protein. Nature 399, 379-383.

Adriani, M., Aoki, J., Horai, R., Thornton, A. M., Konno, A., Kirby, M., Anderson, S. M., Siegel, R. M., Candotti, F., and Schwartzberg, P. L. (2007). Impaired in vitro regulatory $\mathrm{T}$ cell function associated with Wiskott-Aldrich syndrome. Clin. Immunol. 124, 41-48.

Adriani, M., Jones, K. A., Uchiyama, T., Kirby, M. R., Silvin, C., Anderson, S. M., and Candotti, F. (2011). Defective inhibition of B-cell proliferation by Wiskott-Aldrich syndrome protein-deficient regulatory $\mathrm{T}$ cells. Blood 117, 6608-6611.

Albert, M. H., Bittner, T. C., Nonoyama, S., Notarangelo, L. D., Burns, S., Imai, K., Espanol, T., Fasth, A., Pellier, I., Strauss, G., Morio, T., Gathmann, B., Noordzij, J. G., Fillat, C., Hoenig, M., Nathrath, M., Meindl, A., Pagel, P., Wintergerst, U., Fischer, A., Thrasher, A. J., Belohradsky, B. H., and Ochs, H. D. (2010). X-linked thrombocytopenia (XLT) due to WAS mutations: clinical characteristics, long-term outcome, and treatment options. Blood 115, 3231-3238.

Antoine, C., Muller, S., Cant, A., Cavazzana-Calvo, M., Veys, P., Vossen, J., Fasth, A., Heilmann, C., Wulffraat, N., Seger, R., Blanche, S., Friedrich, W., Abinun, M., Davies, G., Bredius, R., Schulz, A., Landais, P., and Fischer, A. (2003). Long-term survival and transplantation of haemopoietic stem cells for immunodeficiencies: report of the European experience 1968-99. Lancet 361, 553-560.

Arkwright, P. D., Abinun, M., and Cant, A. J. (2002). Autoimmunity in human primary immunodeficiency diseases. Blood 99, 2694-2702.

Astrakhan, A., Ochs, H. D., and Rawlings, D. J. (2009). Wiskott-Aldrich syndrome protein is required for homeostasis and function of invariant NKT cells. J. Immunol. 182, 7370-7380.

Azuma, H., Oshima, M., Ito, K., Okuno, A., Kawabata, I., Banba, K., Murahashi, H., Sekine, T., Kato, Y., Ikebuchi, K., and Ikeda, H. (2000). Impaired interleukin-2 production in T-cells from a patient with Wiskott-Aldrich syndrome: basis of clinical effect of interleukin-2 replacement therapy. Eur. J. Pediatr. 159, 633-634.

Azuma, H., Sakata, H., Saijyou, M., and Okuno, A. (1993). Effect of interleukin 2 on intractable herpes virus infection and chronic eczematoid dermatitis in a patient with WiskottAldrich syndrome. Eur. J. Pediatr. 152, 998-1000.

Badour, K., Zhang, J., Shi, F., Leng, Y., Collins, M., and Siminovitch, K. A. (2004). Fyn and PTP-PESTmediated regulation of WiskottAldrich syndrome protein (WASp) tyrosine phosphorylation is required for coupling $\mathrm{T}$ cell antigen receptor engagement to WASp effector function and $\mathrm{T}$ cell activation. J. Exp. Med. 199, 99-112.

Batista, F. D., Treanor, B., and Harwood, N. E. (2010). Visualizing a role for the actin cytoskeleton in the regulation of B-cell activation. Immunol. Rev. 237, 191-204.

Becker-Herman, S., Meyer-Bahlburg, A., Schwartz, M. A., Jackson, S. W., Hudkins, K. L., Liu, C., Sather, B. D., Khim, S., Liggitt, D., Song, W., Silverman, G. J., Alpers, C. E., and Rawlings, D. J. (2011). WASp-deficient B cells play a critical, cell-intrinsic role in triggering autoimmunity. J. Exp. Med. 208, 2033-2042.

Binks, M., Jones, G. E., Brickell, P. M., Kinnon, C., Katz, D. R., and Thrasher, A. J. (1998). Intrinsic dendritic cell abnormalities in WiskottAldrich syndrome. Eur. J. Immunol. 28, 3259-3267.

Blanchoin, L., Amann, K. J., Higgs, H. N., Marchand, J. B., Kaiser, D. A., and Pollard, T. D. (2000). Direct observation of dendritic actin filament networks nucleated by Arp2/3 complex and WASP/Scar proteins. Nature 404, 1007-1011.

Blundell, M. P., Bouma, G., Calle, Y., Jones, G. E., Kinnon, C., and Thrasher, A. J. (2008). Improvement of migratory defects in a murine model of Wiskott-Aldrich syndrome gene therapy. Mol. Ther. 16, 836-844.

Bosticardo, M., Draghici, E., Schena, F., Sauer, A. V., Fontana, E., Castiello, M. C., Catucci, M., Locci, M., Naldini, L., Aiuti, A., Roncarolo, M. G., Poliani, P. L., Traggiai, E., and Villa, A. (2011). Lentiviral-mediated gene therapy leads to improvement of B-cell functionality in a murine model of Wiskott-Aldrich syndrome. J. Allergy Clin. Immunol. 127, 1376-1384 e1375.

Bosticardo, M., Marangoni, F., Aiuti, A., Villa, A., and Grazia Roncarolo, M. (2009). Recent advances in understanding the pathophysiology of Wiskott-Aldrich syndrome. Blood 113, 6288-6295.

Bouma, G., Burns, S., and Thrasher, A. J. (2007). Impaired T-cell priming in vivo resulting from dysfunction of WASp-deficient dendritic cells. Blood 110, 4278-4284.

Bouma, G., Mendoza-Naranjo, A., Blundell, M. P., de Falco, E., Parsley, K. L., Burns, S. O., and Thrasher, A. J. (2011). Cytoskeletal remodeling mediated by WASp in dendritic cells is necessary for normal immune synapse formation and T-cell priming. Blood 118, 2492-2501.

Boztug, K., Schmidt, M., Schwarzer, A., Banerjee, P. P., Diez, I. A., Dewey, R. A., Bohm, M., Nowrouzi, A., Ball, C. R., Glimm, H., Naundorf, S., Kuhlcke, K., Blasczyk, R., Kondratenko, I., Marodi, L., Orange, J. S., von Kalle, C., and Klein, C. (2010). Stem-cell gene therapy for the Wiskott-Aldrich syndrome. $N$. Engl. J. Med. 363, 1918-1927.

Burns, S., Thrasher, A. J., Blundell, M. P., Machesky, L., and Jones, G. E. (2001). Configuration of human dendritic cell cytoskeleton by Rho GTPases, the WAS protein, and differentiation. Blood 98, 1142-1149.

Calle, Y., Chou, H. C., Thrasher, A. J., and Jones, G. E. (2004). WiskottAldrich syndrome protein and the cytoskeletal dynamics of dendritic cells. J. Pathol. 204, 460-469.

Cannon, J. L., and Burkhardt, J. K. (2004). Differential roles for Wiskott-Aldrich syndrome protein in immune synapse formation and IL-2 production. J. Immunol. 173, 1658-1662.

Cassani, B., Poliani, P. L., Marrella, V., Schena, F., Sauer, A. V., Ravanini, M., Strina, D., Busse, C. E., Regenass, S., Wardemann, H., Martini, A., Facchetti, F., van der Burg, M., Rolink, A. G., Vezzoni, P., Grassi, F., Traggiai, E., and Villa, A. (2010). Homeostatic expansion of autoreactive immunoglobulin-secreting cells in the Rag2 mouse model of Omenn syndrome. J. Exp. Med. 207, 1525-1540.

Catucci, M., Prete, F., Bosticardo, M., Castiello, M. C., Draghici, E., Locci, M., Roncarolo, M. G., Aiuti, A., Benvenuti, F., and Villa, A. (2011). Dendritic cell functional improvement in a preclinical model of lentiviralmediated gene therapy for WiskottAldrich syndrome. Gene Ther. doi: 10.1038/gt.2011.202. [Epub ahead of print].

Charrier, S., Dupre, L., Scaramuzza, S., Jeanson-Leh, L., Blundell, M. P., Danos, O., Cattaneo, F., Aiuti, A., Eckenberg, R., Thrasher, A. J.,
Roncarolo, M. G., and Galy, A. (2007). Lentiviral vectors targeting WASp expression to hematopoietic cells, efficiently transduce and correct cells from WAS patients. Gene Ther. 14, 415-428.

Chaturvedi, A., Dorward, D., and Pierce, S. K. (2008). The B cell receptor governs the subcellular location of Toll-like receptor 9 leading to hyperresponses to DNA-containing antigens. Immunity 28, 799-809.

Cianferoni, A., Massaad, M., Feske, S., de la Fuente, M. A., Gallego, L., Ramesh, N., and Geha, R. S. (2005). Defective nuclear translocation of nuclear factor of activated $T$ cells and extracellular signalregulated kinase underlies deficient IL-2 gene expression in WiskottAldrich syndrome. J. Allergy Clin. Immunol. 116, 1364-1371.

Conley, M. E., Saragoussi, D., Notarangelo, L., Etzioni, A., and Casanova, J. L. (2003). An international study examining therapeutic options used in treatment of Wiskott-Aldrich syndrome. Clin. Immunol. 109, 272-277.

Corash, L., Shafer, B., and Blaese, R. M. (1985). Platelet-associated immunoglobulin, platelet size, and the effect of splenectomy in the Wiskott-Aldrich syndrome. Blood 65, 1439-1443.

Cory, G. O., Garg, R., Cramer, R., and Ridley, A. J. (2002). Phosphorylation of tyrosine 291 enhances the ability of WASp to stimulate actin polymerization and filopodium formation. Wiskott-Aldrich syndrome protein. J. Biol. Chem. 277, 45115-45121.

Cory, G. O., Maccarthy-Morrogh, L., Banin, S., Gout, I., Brickell, P. M., Levinsky, R. J., Kinnon, C., and Lovering, R. C. (1996). Evidence that the Wiskott-Aldrich syndrome protein may be involved in lymphoid cell signaling pathways. J. Immunol. 157, 3791-3795.

Critchfield, J. M., Racke, M. K., Zuniga-Pflucker, J. C., Cannella, B., Raine, C. S., Goverman, J., and Lenardo, M. J. (1994). T cell deletion in high antigen dose therapy of autoimmune encephalomyelitis. Science 263, 1139-1143.

Davis, B. R., and Candotti, F. (2009). Revertant somatic mosaicism in the Wiskott-Aldrich syndrome. Immunol. Res. 44, 127-131.

de Meester, J., Calvez, R., Valitutti, S., and Dupre, L. (2010). The WiskottAldrich syndrome protein regulates CTL cytotoxicity and is required for efficient killing of B cell lymphoma targets. J. Leukoc. Biol. 88, 1031-1040. 
de Noronha, S., Hardy, S., Sinclair, J., Blundell, M. P., Strid, J., Schulz, O., Zwirner, J., Jones, G. E., Katz, D. R., Kinnon, C., and Thrasher, A. J. (2005). Impaired dendritic-cell homing in vivo in the absence of Wiskott-Aldrich syndrome protein. Blood 105, 1590-1597.

Derry, J. M., Ochs, H. D., and Francke, U. (1994). Isolation of a novel gene mutated in Wiskott-Aldrich syndrome. Cell 79, 922.

Dupre, L., Aiuti, A., Trifari, S., Martino, S., Saracco, P., Bordignon, C., and Roncarolo, M. G. (2002). WiskottAldrich syndrome protein regulates lipid raft dynamics during immunological synapse formation. Immunity 17, 157-166.

Dupre, L., Marangoni, F., Scaramuzza, S., Trifari, S., Hernandez, R. J., Aiuti, A., Naldini, L., and Roncarolo, M. G. (2006). Efficacy of gene therapy for Wiskott-Aldrich syndrome using a WAS promoter/cDNAcontaining lentiviral vector and nonlethal irradiation. Hum. Gene Ther. 17, 303-313.

Dupuis-Girod, S., Medioni, J., Haddad, E., Quartier, P., Cavazzana-Calvo, M., Le Deist, F., de Saint Basile, G., Delaunay, J., Schwarz, K., Casanova, J. L., Blanche, S., and Fischer, A. (2003). Autoimmunity in WiskottAldrich syndrome: risk factors, clinical features, and outcome in a singlecenter cohort of 55 patients. Pediatrics 111, e622-e627.

Erdei, A., Isaak, A., Torok, K., Sandor, N., Kremlitzka, M., Prechl, J., and Bajtay, Z. (2009). Expression and role of CR1 and CR2 on B and $\mathrm{T}$ lymphocytes under physiological and autoimmune conditions. Mol. Immunol. 46, 2767-2773.

Erikson, J., Radic, M. Z., Camper, S. A., Hardy, R. R., Carmack, C., and Weigert, M. (1991). Expression of anti-DNA immunoglobulin transgenes in non-autoimmune mice. Nature 349, 331-334.

Ettinger, R., Panka, D. J., Wang, J. K., Stanger, B. Z., Ju, S. T., and MarshakRothstein, A. (1995). Fas ligandmediated cytotoxicity is directly responsible for apoptosis of normal $\mathrm{CD} 4+\mathrm{T}$ cells responding to a bacterial superantigen. J. Immunol. 154, 4302-4308.

Evans, J. G., Chavez-Rueda, K. A., Eddaoudi, A., Meyer-Bahlburg, A., Rawlings, D. J., Ehrenstein, M. R., and Mauri, C. (2007). Novel suppressive function of transitional 2 $B$ cells in experimental arthritis. $J$. Immunol. 178, 7868-7878.

Facchetti, F., Blanzuoli, L., Vermi, W., Notarangelo, L. D., Giliani,
S., Fiorini, M., Fasth, A., Stewart, D. M., and Nelson, D. L. (1998). Defective actin polymerization in EBV-transformed B-cell lines from patients with the WiskottAldrich syndrome. J. Pathol. 185, 99-107.

Filipovich, A. H., Stone, J. V., Tomany, S. C., Ireland, M., Kollman, C., Pelz, C. J., Casper, J. T., Cowan, M. J., Edwards, J. R., Fasth, A., Gale, R. P., Junker, A., Kamani, N. R., Loechelt, B. J., Pietryga, D. W., Ringden, O., Vowels, M., Hegland, J., Williams, A. V., Klein, J. P., Sobocinski, K. A., Rowlings, P. A., and Horowitz, M. M. (2001). Impact of donor type on outcome of bone marrow transplantation for Wiskott-Aldrich syndrome: collaborative study of the International Bone Marrow Transplant Registry and the National Marrow Donor Program. Blood 97, 1598-1603.

Fouser, L. A., Wright, J. F., DunussiJoannopoulos, K., and Collins, M. (2008). Th17 cytokines and their emerging roles in inflammation and autoimmunity. Immunol. Rev. 226, 87-102.

Fransen, J. H., Berden, J. H., Koeter, C. M., Adema, G. J., Van Der Vlag, J., and Hilbrands, L. B. (2012). Effect of administration of apoptotic blebs on disease development in lupus mice. Autoimmunity 45, 290-297.

Gaipl, U. S., Voll, R. E., Sheriff, A., Franz, S., Kalden, J. R., and Herrmann, M. (2005). Impaired clearance of dying cells in systemic lupus erythematosus. Autoimmun. Rev. 4, 189-194.

Galy, A., Roncarolo, M. G., and Thrasher, A. J. (2008). Development of lentiviral gene therapy for Wiskott Aldrich syndrome. Expert Opin. Biol. Ther. 8, 181-190.

Garcia-Romo, G. S., Caielli, S., Vega, B., Connolly, J., Allantaz, F., Xu, Z., Punaro, M., Baisch, J., Guiducci, C., Coffman, R. L., Barrat, F. J., Banchereau, J., and Pascual, V. (2011). Netting neutrophils are major inducers of type I IFN production in pediatric systemic lupus erythematosus. Sci. Transl. Med. 3, 73ra20.

Golding, B., Muchmore, A. V., and Blaese, R. M. (1984). Newborn and Wiskott-Aldrich patient B cells can be activated by TNP-Brucella abortus: evidence that TNP-Brucella abortus behaves as a T-independent type 1 antigen in humans. $J$. Immunol. 133, 2966-2971.

Goodnow, C. C. (1996). Balancing immunity and tolerance: deleting and tuning lymphocyte repertoires.
Proc. Natl. Acad. Sci. U.S.A. 93, 2264-2271.

Green, D. R., Droin, N., and Pinkoski, M. (2003). Activation-induced cell death in T cells. Immunol. Rev. 193, 70-81.

Halverson, R., Torres, R. M., and Pelanda, R. (2004). Receptor editing is the main mechanism of B cell tolerance toward membrane antigens. Nat. Immunol. 5, 645-650.

Henriquez, N. V., Rijkers, G. T., and Zegers, B. J. (1994). Antigen receptor-mediated transmembrane signaling in Wiskott-Aldrich syndrome. J. Immunol. 153, 395-399.

Humblet-Baron, S., Sather, B., Anover, S., Becker-Herman, S., Kasprowicz, D. J., Khim, S., Nguyen, T., HudkinsLoya, K., Alpers, C. E., Ziegler, S. F., Ochs, H., Torgerson, T., Campbell, D. J., and Rawlings, D. J. (2007). Wiskott-Aldrich syndrome protein is required for regulatory $\mathrm{T}$ cell homeostasis. J. Clin. Invest. 117, 407-418.

Imai, K., Morio, T., Zhu, Y., Jin, Y., Itoh, S., Kajiwara, M., Yata, J., Mizutani, S., Ochs, H. D., and Nonoyama, S. (2004). Clinical course of patients with WASP gene mutations. Blood 103, 456-464.

Imai, K., Nonoyama, S., Miki, H., Morio, T., Fukami, K., Zhu, Q. Aruffo, A., Ochs, H. D., Yata, J., and Takenawa, T. (1999). The pleckstrin homology domain of the WiskottAldrich syndrome protein is involved in the organization of actin cytoskeleton. Clin. Immunol. 92, 128-137.

Isaksson, M., Ardesjo, B., Ronnblom, L., Kampe, O., Lassmann, H., Eloranta, M. L., and Lobell, A. (2009). Plasmacytoid DC promote priming of autoimmune Th17 cells and EAE. Eur. J. Immunol. 39, 2925-2935.

Isnardi, I., Ng, Y. S., Srdanovic, I., Motaghedi, R., Rudchenko, S., Von Bernuth, H., Zhang, S. Y., Puel, A., Jouanguy, E., Picard, C., Garty, B. Z., Camcioglu, Y., Doffinger, R., Kumararatne, D., Davies, G., Gallin, J. I., Haraguchi, S., Day, N. K., Casanova, J. L., and Meffre, E. (2008). IRAK-4- and MyD88dependent pathways are essential for the removal of developing autoreactive B cells in humans. Immunity 29 746-757.

Jin, Y., Mazza, C., Christie, J. R., Giliani, S., Fiorini, M., Mella, P., Gandellini, F., Stewart, D. M., Zhu, Q. Nelson, D. L., Notarangelo, L. D., and Ochs, H. D. (2004). Mutations of the Wiskott-Aldrich syndrome protein (WASP): hotspots, effect on transcription, and translation and phenotype/genotype correlation. Blood 104, 4010-4019.

Kim, A. S., Kakalis, L. T., Abdul-Manan, N., Liu, G. A., and Rosen, M. K. (2000). Autoinhibition and activation mechanisms of the WiskottAldrich syndrome protein. Nature 404, 151-158.

Kim, J. J., Thrasher, A. J., Jones, A. M., Davies, E. G., and Cale, C. M. (2007). Rituximab for the treatment of autoimmune cytopenias in children with immune deficiency. $B r . J$. Haematol. 138, 94-96.

Kobayashi, R., Ariga, T., Nonoyama, S., Kanegane, H., Tsuchiya, S., Morio, T., Yabe, H., Nagatoshi, Y., Kawa, K., Tabuchi, K., Tsuchida, M., Miyawaki, T., and Kato, S. (2006). Outcome in patients with Wiskott-Aldrich syndrome following stem cell transplantation: an analysis of 57 patients in Japan. Br. J. Haematol. 135, 362-366.

Kolluri, R., Tolias, K. F., Carpenter, C. L., Rosen, F. S., and Kirchhausen, T. (1996). Direct interaction of the Wiskott-Aldrich syndrome protein with the GTPase Cdc42. Proc. Natl. Acad. Sci. U.S.A. 93, 5615-5618.

Langrish, C. L., Chen, Y., Blumenschein, W. M., Mattson, J., Basham, B., Sedgwick, J. D., Mcclanahan, T., Kastelein, R. A., and Cua, D. J. (2005). IL-23 drives a pathogenic $\mathrm{T}$ cell population that induces autoimmune inflammation. J. Exp. Med. 201, 233-240.

Lau, C. M., Broughton, C., Tabor, A. S., Akira, S., Flavell, R. A., Mamula, M. J., Christensen, S. R., Shlomchik, M. J., Viglianti, G. A., Rifkin, I. R., and Marshak-Rothstein, A. (2005). RNA-associated autoantigens activate $B$ cells by combined $B$ cell antigen receptor/Toll-like receptor 7 engagement. J. Exp. Med. 202, 1171-1177.

Leadbetter, E. A., Rifkin, I. R., Hohlbaum, A. M., Beaudette, B. C., Shlomchik, M. J., and Marshak-Rothstein, A. (2002) Chromatin-IgG complexes activate B cells by dual engagement of IgM and Toll-like receptors. Nature 416 603-607.

Lenardo, M. J. (1991). Interleukin-2 programs mouse alpha beta $\mathrm{T}$ lymphocytes for apoptosis. Nature 353, 858-861.

Lenert, P., Brummel, R., Field, E. H., and Ashman, R. F. (2005) TLR-9 activation of marginal zone $\mathrm{B}$ cells in lupus mice regulates immunity through increased IL-10 production. J. Clin. Immunol. 25, 29-40.

Leverrier, Y., Lorenzi, R., Blundell, M. P., Brickell, P., Kinnon, C., Ridley, A. J., and Thrasher, A. J. (2001). 
Cutting edge: the Wiskott-Aldrich syndrome protein is required for efficient phagocytosis of apoptotic cells. J. Immunol. 166, 4831-4834.

Linder, S., Nelson, D., Weiss, M., and Aepfelbacher, M. (1999). WiskottAldrich syndrome protein regulates podosomes in primary human macrophages. Proc. Natl. Acad. Sci. U.S.A. 96, 9648-9653.

Locci, M., Draghici, E., Marangoni, F., Bosticardo, M., Catucci, M., Aiuti, A., Cancrini, C., Marodi, L., Espanol, T., Bredius, R. G., Thrasher, A. J., Schulz, A., Litzman, J., Roncarolo, M. G., Casorati, G., Dellabona, P., and Villa, A. (2009). The Wiskott-Aldrich syndrome protein is required for iNKT cell maturation and function. J. Exp. Med. 206, 735-742.

Machesky, L. M., and Gould, K. L. (1999). The Arp $2 / 3$ complex: a multifunctional actin organizer. Curr. Opin. Cell Biol. 11, 117-121.

Machesky, L. M., and Insall, R. H. (1998). Scarl and the related Wiskott-Aldrich syndrome protein, WASP, regulate the actin cytoskeleton through the Arp2/3 complex. Curr. Biol. 8, 1347-1356.

Maillard, M. H., Cotta-de-Almeida, V., Takeshima, F., Nguyen, D. D., Michetti, P., Nagler, C., Bhan, A. K., and Snapper, S. B. (2007). The Wiskott-Aldrich syndrome protein is required for the function of CD4(+)CD25(+)Foxp3(+) regulatory $\mathrm{T}$ cells. J. Exp. Med. 204, 381-391.

Manicassamy, S., and Pulendran, B. (2011). Dendritic cell control of tolerogenic responses. Immunol. Rev. 241, 206-227.

Marangoni, F., Bosticardo, M., Charrier, S., Draghici, E., Locci, M., Scaramuzza, S., Panaroni, C., Ponzoni, M., Sanvito, F., Doglioni, C., Liabeuf, M., Gjata, B., Montus, M., Siminovitch, K., Aiuti, A., Naldini, L., Dupre, L., Roncarolo, M. G., Galy, A., and Villa, A. (2009). Evidence for long-term efficacy and safety of gene therapy for Wiskott-Aldrich syndrome in preclinical models. Mol. Ther. 17, 1073-1082.

Marangoni, F., Trifari, S., Scaramuzza, S., Panaroni, C., Martino, S., Notarangelo, L. D., Baz, Z., Metin, A., Cattaneo, F., Villa, A., Aiuti, A., Battaglia, M., Roncarolo, M. G., and Dupre, L. (2007). WASP regulates suppressor activity of human and murine $\mathrm{CD} 4(+) \mathrm{CD} 25(+) \mathrm{FOXP} 3(+)$ natural regulatory T cells. J. Exp. Med. 204, 369-380.
Marathe, B. M., Prislovsky, A., Astrakhan, A., Rawlings, D. J., Wan, J. Y., and Strom, T. S. (2009). Antiplatelet antibodies in WASP(-) mice correlate with evidence of increased in vivo platelet consumption. Exp. Hematol. 37, 1353-1363.

Mars, L. T., Araujo, L., Kerschen, P., Diem, S., Bourgeois, E., Van, L. P., Carrie, N., Dy, M., Liblau, R. S., and Herbelin, A. (2009). Invariant NKT cells inhibit development of the Th17 lineage. Proc. Natl. Acad. Sci. U.S.A. 106, 6238-6243.

Matsushita, T., Yanaba, K., Bouaziz, J. D., Fujimoto, M., and Tedder, T. F. (2008). Regulatory B cells inhibit EAE initiation in mice while other $B$ cells promote disease progression. J. Clin. Invest. 118, 3420-3430.

Meffre, E. (2011). The establishment of early B cell tolerance in humans: lessons from primary immunodeficiency diseases. Ann. N. Y. Acad. Sci. 1246, 1-10.

Meyer-Bahlburg, A., Becker-Herman, S., Humblet-Baron, S., Khim, S., Weber, M., Bouma, G., Thrasher, A. J., Batista, F. D., and Rawlings, D. J. (2008). Wiskott-Aldrich syndrome protein deficiency in B cells results in impaired peripheral homeostasis. Blood 112, 4158-4169.

Miki, H., Suetsugu, S., and Takenawa, T. (1998). WAVE, a novel WASP-family protein involved in actin reorganization induced by Rac. $E M B O$ J. 17, 6932-6941.

Miyamoto, K., Miyake, S., and Yamamura, T. (2001). A synthetic glycolipid prevents autoimmune encephalomyelitis by inducing $\mathrm{TH} 2$ bias of natural killer T cells. Nature 413, 531-534.

Molina, I. J., Kenney, D. M., Rosen, F. S., and Remold-O'Donnell, E. (1992). $\mathrm{T}$ cell lines characterize events in the pathogenesis of the WiskottAldrich syndrome. J. Exp. Med. 176, 867-874.

Molina, I. J., Sancho, J., Terhorst, C., Rosen, F. S., and Remold-O'Donnell, E. (1993). T cells of patients with the Wiskott-Aldrich syndrome have a restricted defect in proliferative responses. J. Immunol. 151, 4383-4390.

Monroe, J. G., and Dorshkind, K. (2007). Fate decisions regulating bone marrow and peripheral B lymphocyte development. Adv. Immunol. 95, 1-50.

Moratto, D., Giliani, S., Bonfim, C., Mazzolari, E., Fischer, A., Ochs, H. D., Cant, A. J., Thrasher, A. J., Cowan, M. J., Albert, M. H., Small, T., Pai,
S. Y., Haddad, E., Lisa, A., Hambleton, S., Slatter, M., Cavazzana-Calvo, M., Mahlaoui, N., Picard, C., Torgerson, T. R., Burroughs, L., Koliski, A., Neto, J. Z., Porta, F., Qasim, W., Veys, P., Kavanau, K., Honig, M., Schulz, A., Friedrich, W., and Notarangelo, L. D. (2011). Long-term outcome and lineage-specific chimerism in 194 patients with Wiskott-Aldrich syndrome treated by hematopoietic cell transplantation in the period 19802009: an international collaborative study. Blood 118, 1675-1684.

Mullen, C. A., Anderson, K. D., and Blaese, R. M. (1993). Splenectomy and/or bone marrow transplantation in the management of the Wiskott-Aldrich syndrome: longterm follow-up of 62 cases. Blood 82 , 2961-2966.

Nemazee, D. A., and Burki, K. (1989). Clonal deletion of B lymphocytes in a transgenic mouse bearing antiMHC class I antibody genes. Nature 337, 562-566.

Ng, Y. S., Wardemann, H., Chelnis, J., Cunningham-Rundles, C., and Meffre, E. (2004). Bruton's tyrosine kinase is essential for human B cell tolerance. J. Exp. Med. 200, 927-934.

Nikolov, N. P., Shimizu, M., Cleland, S., Bailey, D., Aoki, J., Strom, T., Schwartzberg, P. L., Candotti, F., and Siegel, R. M. (2010). Systemic autoimmunity and defective Fas ligand secretion in the absence of the Wiskott-Aldrich syndrome protein. Blood 116, 740-747.

Nishie, T., Miyaishi, O., Azuma, H., Kameyama, A., Naruse, C., Hashimoto, N., Yokoyama, H. Narimatsu, H., Wada, T., and Asano, M. (2007). Development of immunoglobulin A nephropathy- like disease in beta1,4-galactosyltransferase-I-deficient mice. Am. J. Pathol. 170, 447-456.

Notarangelo, L. D., Mazza, C., Giliani, S., D’Aria, C., Gandellini, F., Ravelli, C., Locatelli, M. G., Nelson, D. L., Ochs, H. D., and Notarangelo, L. D. (2002). Missense mutations of the WASP gene cause intermittent $\mathrm{X}$ linked thrombocytopenia. Blood 99, 2268-2269.

Ochs, H. D. (2002). The WiskottAldrich syndrome. Isr. Med. Assoc. J. 4, 379-384.

Ochs, H. D., Filipovich, A. H., Veys, P., Cowan, M. J., and Kapoor, N. (2009). Wiskott-Aldrich syndrome: diagnosis, clinical and laboratory manifestations, and treatment. Biol. Blood Marrow Transplant. 15, 84-90.
Ochs, H. D., and Thrasher, A. J. (2006). The Wiskott-Aldrich syndrome. $J$. Allergy Clin. Immunol. 117, 725-738; quiz 739.

Oh, K., Byoun, O. J., Ham, D. I., Kim, Y. S., and Lee, D. S. (2011). Invariant NKT cells regulate experimental autoimmune uveitis through inhibition of Th17 differentiation. Eur. J. Immunol. 41, 392-402.

Orange, J. S., Ramesh, N., RemoldO'Donnell, E., Sasahara, Y., Koopman, L., Byrne, M., Bonilla, F. A., Rosen, F. S., Geha, R. S., and Strominger, J. L. (2002). Wiskott-Aldrich syndrome protein is required for $\mathrm{NK}$ cell cytotoxicity and colocalizes with actin to NK cell-activating immunologic synapses. Proc. Natl. Acad. Sci. U.S.A. 99, 11351-11356.

Orange, J. S., Roy-Ghanta, S., Mace, E. M., Maru, S., Rak, G. D., Sanborn, K. B., Fasth, A., Saltzman, R., Paisley, A., Monaco-Shawver, L., Banerjee, P. P., and Pandey, R. (2011). IL-2 induces a WAVE2-dependent pathway for actin reorganization that enables WASp-independent human NK cell function. J. Clin. Invest. 121, 1535-1548.

Ozsahin, H., Cavazzana-Calvo, M., Notarangelo, L. D., Schulz, A. Thrasher, A. J., Mazzolari, E., Slatter, M. A., Le Deist, F., Blanche, S., Veys, P., Fasth, A., Bredius, R., Sedlacek, P., Wulffraat, N., Ortega, J., Heilmann, C., O'Meara, A., Wachowiak, J., Kalwak, K., MatthesMartin, S., Gungor, T., Ikinciogullari, A., Landais, P., Cant, A. J., Friedrich, W., and Fischer, A. (2008). Longterm outcome following hematopoietic stem-cell transplantation in Wiskott-Aldrich syndrome: collaborative study of the European Society for Immunodeficiencies and European Group for Blood and Marrow Transplantation. Blood 111, 439-445.

Ozsahin, H., Le Deist, F., Benkerrou, M., Cavazzana-Calvo, M., Gomez, L., Griscelli, C., Blanche, S., and Fischer, A. (1996). Bone marrow transplantation in 26 patients with WiskottAldrich syndrome from a single center. J. Pediatr. 129, 238-244.

Pai, S. Y., Demartiis, D., Forino, C., Cavagnini, S., Lanfranchi, A., Giliani, S., Moratto, D., Mazza, C., Porta, F., Imberti, L., Notarangelo, L. D., and Mazzolari, E. (2006). Stem cell transplantation for the Wiskott-Aldrich syndrome: a singlecenter experience confirms efficacy of matched unrelated donor transplantation. Bone Marrow Transplant. $38,671-679$. 
Pantaloni, D., Boujemaa, R., Didry, D., Gounon, P., and Carlier, M. F. (2000). The Arp $2 / 3$ complex branches filament barbed ends: functional antagonism with capping proteins. Nat. Cell Biol. 2, 385-391.

Park, H., Chan, M. M., and Iritani, B. M. (2010). Hem-1: putting the "WAVE" into actin polymerization during an immune response. FEBS Lett. 584, 4923-4932.

Park, J. Y., Shcherbina, A., Rosen, F. S., Prodeus, A. P., and RemoldO'Donnell, E. (2005). Phenotypic perturbation of $\mathrm{B}$ cells in the Wiskott-Aldrich syndrome. Clin. Exp. Immunol. 139, 297-305.

Prodeus, A. P., Goerg, S., Shen, L. M., Pozdnyakova, O. O., Chu, L., Alicot, E. M., Goodnow, C. C., and Carroll, M. C. (1998). A critical role for complement in maintenance of self-tolerance. Immunity 9, 721-731.

Pulecio, J., Tagliani, E., Scholer, A., Prete, F., Fetler, L., Burrone, O. R., and Benvenuti, F. (2008). Expression of Wiskott-Aldrich syndrome protein in dendritic cells regulates synapse formation and activation of naive CD8+ T cells. J. Immunol. 181, 1135-1142.

Ramesh, N., Anton, I. M., Hartwig, J. H., and Geha, R. S. (1997). WIP, a protein associated with wiskottaldrich syndrome protein, induces actin polymerization and redistribution in lymphoid cells. Proc. Natl. Acad. Sci. U.S.A. 94, 14671-14676.

Recher, M., Burns, S. O., de la Fuente, M. A., Volpi, S., Dahlberg, C., Walter, J. E., Moffitt, K., Mathew, D., Honke, N., Lang, P. A., Patrizi, L., Falet, H., Keszei, M., Mizui, M., Csizmadia, E., Candotti, F., Nadeau, K., Bouma, G., Delmonte, O. M., Frugoni, F., Fomin, A. B., Buchbinder, D., Lundequist, E. M., Massaad, M. J., Tsokos, G. C., Hartwig, J., Manis, J., Terhorst, C., Geha, R. S., Snapper, S., Lang, K. S., Malley, R., Westerberg, L., Thrasher, A. J., and Notarangelo, L. D. (2012). B cell-intrinsic deficiency of the Wiskott-Aldrich syndrome protein (WASp) causes severe abnormalities of the peripheral Bcell compartment in mice. Blood 119, 2819-2828.

Ronnblom, L. (2011). The type I interferon system in the etiopathogenesis of autoimmune diseases. Ups. J. Med. Sci. 116, 227-237.

Sakaguchi, S., Yamaguchi, T., Nomura, T., and Ono, M. (2008). Regulatory $\mathrm{T}$ cells and immune tolerance. Cell 133, 775-787.

Scaramuzza, S., Biasco, L., Ripamonti, A., Castiello, M. C., Loperfido, M., Draghici, E., Hernandez,
R. J., Benedicenti, F., Radrizzani, M., Salomoni, M., Ranzani, M., Bartholomae, C. C., Vicenzi, E., Finocchi, A., Bredius, R., Bosticardo, M., Schmidt, M., Von Kalle, C., Montini, E., Biffi, A., Roncarolo, M. G., Naldini, L., Villa, A., and Aiuti, A. (2012). Preclinical safety and efficacy of human CD34 $(+)$ cells transduced with lentiviral vector for the treatment of Wiskott-Aldrich syndrome. Mol. Ther. doi: 10.1038/mt.2012.23. [Epub ahead of print]

Schurman, S. H., and Candotti, F. (2003). Autoimmunity in WiskottAldrich syndrome. Curr. Opin. Rheumatol. 15, 446-453.

Semple, J. W., Siminovitch, K. A., Mody, M., Milev, Y., Lazarus, A. H., Wright, J. F., and Freedman, J. (1997). Flow cytometric analysis of platelets from children with the WiskottAldrich syndrome reveals defects in platelet development, activation and structure. Br. J. Haematol. 97, 747-754.

Sharma, M. D., Hou, D. Y., Liu, Y., Koni, P. A., Metz, R., Chandler, P., Mellor, A. L., He, Y., and Munn, D. H. (2009). Indoleamine 2,3-dioxygenase controls conversion of Foxp3+ Tregs to TH17-like cells in tumor-draining lymph nodes. Blood 113, 6102-6111. Shcherbina, A., Cooley, J., Lutskiy, M. I., Benarafa, C., Gilbert, G. E., and Remold-O'Donnell, E. (2009). WASP plays a novel role in regulating platelet responses dependent on alphaIIbbeta3 integrin outsidein signalling. Br. J. Haematol. 148, 416-427.

Shimizu, M., Nikolov, N. P., Ueno, K., Ohta, K., Siegel, R. M., Yachie, A., and Candotti, F. (2012). Development of IgA nephropathy-like glomerulonephritis associated with Wiskott-Aldrich syndrome protein deficiency. Clin. Immunol. 142, 160-166.

Ship, A., May, W., and Lucas, K. (2002). Anti-CD20 monoclonal antibody therapy for autoimmune hemolytic anemia following $\mathrm{T}$ cell-depleted, haplo-identical stem cell transplantation. Bone Marrow Transplant. 29, 365-366.

Siegel, R. M., Chan, F. K., Chun, H. J., and Lenardo, M. J. (2000). The multifaceted role of Fas signaling in immune cell homeostasis and autoimmunity. Nat. Immunol. 1, 469-474.

Simon, H. U., Mills, G. B., Hashimoto, S., and Siminovitch, K. A. (1992). Evidence for defective transmembrane signaling in B cells from patients with Wiskott-Aldrich syndrome. J. Clin. Invest. 90, 1396-1405.
Sims, T. N., Soos, T. J., Xenias, H. S., Dubin-Thaler, B., Hofman, J. M., Waite, J. C., Cameron, T. O. Thomas, V. K., Varma, R., Wiggins, C. H., Sheetz, M. P., Littman, D. R., and Dustin, M. L. (2007). Opposing effects of PKCtheta and WASp on symmetry breaking and relocation of the immunological synapse. Cell 129, 773-785.

Singh, A. K., Wilson, M. T., Hong, S., Olivares-Villagomez, D., Du, C., Stanic, A. K., Joyce, S., Sriram, S., Koezuka, Y., and Van Kaer, L. (2001). Natural killer $\mathrm{T}$ cell activation protects mice against experimental autoimmune encephalomyelitis. J. Exp. Med. 194, 1801-1811.

Snapper, S. B., Rosen, F. S., Mizoguchi, E., Cohen, P., Khan, W., Liu, C. H., Hagemann, T. L., Kwan, S. P., Ferrini, R., Davidson, L., Bhan, A. K., and Alt, F. W. (1998). Wiskott-Aldrich syndrome protein-deficient mice reveal a role for WASP in T but not B cell activation. Immunity 9, 81-91.

Stewart, D. M., Candotti, F., and Nelson, D. L. (2007). The phenomenon of spontaneous genetic reversions in the Wiskott-Aldrich syndrome: a report of the workshop of the ESID Genetics Working Party at the XIIth Meeting of the European Society for Immunodeficiencies (ESID). Budapest, Hungary October 4-7, 2006. J. Clin. Immunol. 27, 634-639.

Sullivan, K. E., Mullen, C. A., Blaese, R. M., and Winkelstein, J. A. (1994). A multiinstitutional survey of the Wiskott-Aldrich syndrome. J. Pediatr. 125, 876-885.

Symons, M., Derry, J. M., Karlak, B. Jiang, S., Lemahieu, V., Mccormick, F., Francke, U., and Abo, A. (1996). Wiskott-Aldrich syndrome protein, a novel effector for the GTPase CDC42Hs, is implicated in actin polymerization. Cell 84, 723-734.

Taylor, M. D., Sadhukhan, S., Kottangada, P., Ramgopal, A., Sarkar, K., D'Silva, S., Selvakumar, A., Candotti, F., and Vyas, Y. M. (2010). Nuclear role of WASp in the pathogenesis of dysregulated TH1 immunity in human Wiskott-Aldrich syndrome. Sci. Transl. Med. 2, 37ra44.

Tomasevic, N., Jia, Z., Russell, A., Fujii, T., Hartman, J. J., Clancy, S., Wang, M., Beraud, C., Wood, K. W., and Sakowicz, R. (2007). Differential regulation of WASP and N-WASP by Cdc42, Racl, Nck, and $\mathrm{PI}(4,5) \mathrm{P} 2$. Biochemistry 46, 3494-3502.

Townsend, M. J., Monroe, J. G., and Chan, A. C. (2010). B-cell targeted therapies in human autoimmune diseases: an updated perspective. Immunol. Rev. 237, 264-283.

Trifari, S., Scaramuzza, S., Catucci, M., Ponzoni, M., Mollica, L., Chiesa, R., Cattaneo, F., Lafouresse, F., Calvez, R., Vermi, W., Medicina, D., Castiello, M. C., Marangoni, F., Bosticardo, M., Doglioni, C., Caniglia, M., Aiuti, A., Villa, A., Roncarolo, M. G., and Dupre, L. (2010). Revertant T lymphocytes in a patient with Wiskott-Aldrich syndrome: analysis of function and distribution in lymphoid organs. J. Allergy Clin. Immunol. 125, 439-448 e438.

Trifari, S., Sitia, G., Aiuti, A., Scaramuzza, S., Marangoni, F., Guidotti, L. G., Martino, S., Saracco, P., Notarangelo, L. D., Roncarolo, M. G., and Dupre, L. (2006). Defective Thl cytokine gene transcription in CD4+ and CD8+ T cells from Wiskott-Aldrich syndrome patients. J. Immunol. 177, 7451-7461.

Tsuboi, S., and Meerloo, J. (2007). Wiskott-Aldrich syndrome protein is a key regulator of the phagocytic cup formation in macrophages. J. Biol. Chem. 282, 34194-34203.

Villa, A., Notarangelo, L., Macchi, P., Mantuano, E., Cavagni, G., Brugnoni, D., Strina, D., Patrosso, M. C., Ramenghi, U., Sacco, M. G., Ugazio, A., and Vezzoni, P. (1995). X-linked thrombocytopenia and Wiskott-Aldrich syndrome are allelic diseases with mutations in the WASP gene. Nat. Genet. 9, 414-417. von Boehmer, H., and Melchers, F. (2010). Checkpoints in lymphocyte development and autoimmune disease. Nat. Immunol. 11, 14-20.

Watanabe, R., Ishiura, N., Nakashima, H., Kuwano, Y., Okochi, H., Tamaki, K., Sato, S., Tedder, T. F., and Fujimoto, M. (2010). Regulatory B cells (B10 cells) have a suppressive role in murine lupus: CD19 and B10 cell deficiency exacerbates systemic autoimmunity. J. Immunol. 184, 4801-4809.

Weant, A. E., Michalek, R. D., Khan, I. U., Holbrook, B. C., Willingham, M. C., and Grayson, J. M. (2008). Apoptosis regulators Bim and Fas function concurrently to control autoimmunity and CD8+ T cell contraction. Immunity 28, 218-230.

Welch, M. D., and Mullins, R. D. (2002). Cellular control of actin nucleation. Annu. Rev. Cell Dev. Biol. 18, 247-288.

Wermeling, F., Lind, S. M., Jordo, E. D., Cardell, S. L., and Karlsson, M. C. (2010). Invariant NKT cells limit activation of autoreactive 
CD1d-positive B cells. J. Exp. Med. 207, 943-952.

Westerberg, L., Larsson, M., Hardy, S. J., Fernandez, C., Thrasher, A. J., and Severinson, E. (2005). WiskottAldrich syndrome protein deficiency leads to reduced B-cell adhesion, migration, and homing, and a delayed humoral immune response. Blood 105, 1144-1152.

Westerberg, L., Wallin, R. P., Greicius, G., Ljunggren, H. G., and Severinson, E. (2003). Efficient antigen presentation of soluble, but not particulate, antigen in the absence of Wiskott-Aldrich syndrome protein. Immunology 109, 384-391.

Westerberg, L. S., de la Fuente, M. A., Wermeling, F., Ochs, H. D., Karlsson, M. C., Snapper, S. B., and Notarangelo, L. D. (2008). WASP confers selective advantage for specific hematopoietic cell populations and serves a unique role in marginal zone B-cell homeostasis and function. Blood 112, 4139-4147.

Yanaba, K., Bouaziz, J. D., Matsushita, T., Tsubata, T., and Tedder, T. F. (2009). The development and function of regulatory $B$ cells expressing IL-10 (B10 cells) requires antigen receptor diversity and TLR signals. J. Immunol. 182, 7459-7472.

Yang, J. Q., Wen, X., Kim, P. J., and Singh, R. R. (2011). Invariant NKT cells inhibit autoreactive $B$ cells in a contact- and CD1ddependent manner. J. Immunol. 186, 1512-1520.

Zhang, H., Schaff, U. Y., Green, C. E., Chen, H., Sarantos, M. R., Hu, Y., Wara, D., Simon, S. I., and Lowell, C. A. (2006). Impaired integrindependent function in WiskottAldrich syndrome protein-deficient murine and human neutrophils. Immunity 25, 285-295.
Zhang, J., Shehabeldin, A., da Cruz, L. A., Butler, J., Somani, A. K., Mcgavin, M., Kozieradzki, I., Dos Santos, A. O., Nagy, A., Grinstein, S. Penninger, J. M., and Siminovitch, K. A. (1999). Antigen receptorinduced activation and cytoskeletal rearrangement are impaired in Wiskott-Aldrich syndrome proteindeficient lymphocytes. J. Exp. Med. 190, 1329-1342.

Zhu, Q., Watanabe, C., Liu, T., Hollenbaugh, D., Blaese, R. M., Kanner, S. B., Aruffo, A., and Ochs, H. D. (1997). WiskottAldrich syndrome/X-linked thrombocytopenia: WASP gene mutations, protein expression, and phenotype. Blood 90, 2680-2689.

Conflict of Interest Statement: The authors declare that the research was conducted in the absence of any commercial or financial relationships that could be construed as a potential conflict of interest.

Received: 23 April 2012; paper pending published: 06 May 2012; accepted: 01 July 2012; published online: 18 July 2012.

Citation: Catucci M, Castiello MC, Pala F, Bosticardo $M$ and Villa A (2012) Autoimmunity in Wiskott-Aldrich syndrome: an unsolved enigma. Front. Immun. 3:209. doi: 10.3389/fimmu.2012.00209

This article was submitted to Frontiers in Primary Immunodeficiencies, a specialty of Frontiers in Immunology.

Copyright ๑) 2012 Catucci, Castiello, Pala, Bosticardo and Villa. This is an open-access article distributed under the terms of the Creative Commons Attribution License, which permits use, distribution and reproduction in other forums, provided the original authors and source are credited and subject to any copyright notices concerning any third-party graphics etc. 